\title{
Interface between Competition law and Intellectual Property Rights: A Comparative Study of the US, EU and India Raju KD*
}

International Law at Rajiv Gandhi School of IP Law, IIT Kharagpur and Life Member, Indian Society of International Law, New Delhi, India

\begin{abstract}
It is generally viewed that Intellectual property protection and competition law are odds with each other. Is there really any tussle between intellectual property protection and competition law? Intellectual property law creates and protects monopoly power and the other seeks to exclude it. IP exclusion provisions are included in the Indian Competition Act, 2002 in Section 3(5). This is to provide enforcement to intellectual property rights. But protection of intellectual property rights are not per se violates any competition provisions. The objective of competition law is to prohibit anti-competitive practices and the objective of both the stream is wealth maximization in any economy. Intellectual property protection is necessary to foster innovation and choices of products in the market. It infuses efficiency in the market and increases consumer welfare.

India is in the nascent state of its administration of competition laws. There are sizable number of cases came before the Indian competition authorities $(\mathrm{CCl})$ and Indian courts. Cases against Microsoft India and abuse of dominant case against Ericsson filed by an Indian company named Micromax is only the beginning of the interface cases on intellectual property and competition law. There is no sufficient case laws and jurisprudence is available in India in guiding the Indian authorities and courts on the interface between intellectual property and competition. It is necessary to make an analysis of the jurisprudence in the US and EU.

First part of this paper deals with the US Antitrust Act, 1890 and analysis of a number of cases dealt by the US courts. The EU Regulations and cases are clearer on issues of intellectual property and competition law. Indian jurisprudence is not clear so far and few cases are dealt by the $\mathrm{CCl}$ and Indian courts. The study concludes that Indian authorities should learn from other jurisdictions and the jurisprudence will act as guideline for Indian authorities.
\end{abstract}

Keywords: Intellectual property rights; Completion law; India

\section{Introduction}

The aim of competition policy in the economy of a country is to ensure fair competition in the market by way of regulatory mechanisms. It is not intended to create restrictions or constrictions that may be detrimental to the growth of the society. Its focus is the avoidance of market domination by a handful through different modes such as price fixing or market sharing cartels and undue concentration. It also aims at promoting competition as a means of market response and consumer preference so as to ensure effective and efficient allocation of resources and to create an incentive for the economy for innovation ${ }^{1}$. Companies can monopolise their technologies for a limited period of time, but they cannot maintain a monopoly over the market. Intellectual property protection per se is not abusive but ironically, if it dominates over the market it is only doing a legitimate job of its purpose, namely to create to incentive for further innovation. However, when companies refrain from licensing their intellectual property to competitors, they undermine the basic tenets of competition law as well as the spirit of intellectual property protection.

At the outset, it does seem like both the concepts are at loggerheads with each other in their areas of operation. However, anti-trust laws and patent laws co-exist as has been rightly held by a 1948 US Supreme Court opinion which has described the boundaries of the immunity this way 'the possession of a valid patent or patents does not give the patentee any exemption from the provisions of the Sherman Act beyond the limits of the patent monopoly.'2 Hence, a strong

${ }^{1}$ UNCTAD Secretariat, Objectives of Competition Law and policy: Towards a Coherent Strategy for Promoting Competition and Development,

${ }^{2}$ United States v. Line Material Co., 333 U.S. 287, 308, 76 U.S.P.Q. (BNA) 399 408 (1948) (patent pool struck down on price fixing grounds apparently without examination of pro-competitive effects of pool on innovation and consumer welfare). competition law can provide a solution by preventing anti-competitive agreements and improving economic efficiency and consumer welfare. It can be concluded that the twin objective of competition law is to protect consumer welfare as well as the economic freedom of market players [1]. A study of competition policy reveals the requirement of various kinds of state interventions that affect acquisition and the use of IPRs [2]. When a patent holder adopts any kind of anti-competitive practices, governments can adopt measures like the compulsory licensing of such technologies under the provisions of the WTO Trade Related Aspects of Intellectual Property Law (TRIPs) Agreement ${ }^{3}$.

Unilateral refusal to license a patent (refusal to deal) can be considered as a ground for compulsory licenses. Under the 'essential facilities' doctrine, refusal of the sharing of a technology can be a ground for compulsory licensing to a third party, particularly if the facility is not available to the applicant at reasonable rates in order to compete with the others in the market. 'Patent thickets'4 are also pointed out ${ }^{3}$ Article 31(b) of the TRIPs Agreement.

${ }^{4} \mathrm{~A}$ dense web of overlapping intellectual property rights claims are known as a patent thicket.

*Corresponding author: Raju KD, Associate Professor of International Law at Rajiv Gandhi School of IP Law, IIT Kharagpur, India and Life Member, Indian Society of International Law, New Delhi, India, Tel: +91-9434744126; E-mail: rajukd@gmail.com

Received January 31, 2014; Accepted April 04, 2014; Published April 10, 2014

Citation: Raju KD (2014) Interface between Competition law and Intellectual Property Rights: A Comparative Study of the US, EU and India. Intel Prop Rights 2: 115. doi:10.4172/2375-4516.1000115

Copyright: (c) 2014 Raju KD. This is an open-access article distributed under the terms of the Creative Commons Attribution License, which permits unrestricted use, distribution, and reproduction in any medium, provided the original author and source are credited. 
to be disadvantageous to competition especially since they extend the period of the patent claims to an indefinite period. Copyright law is also involved in important competition law cases such as the Microsoft case. The tension between trademarks and competition law also can be seen in some of the cases.

The basic question involving anti-trust and intellectual property protection is whether the goal of anti-trust laws which is the preserving of competition in high-tech markets promotes or retards long term innovation in the economy? The landmark Microsoft case takes center stage in this whole debate on anti-trust law and intellectual property protection.

Intellectual Property Rights (IPRs) protection and Competition law have evolved historically as two systems of law. The traditional role of competition law has been to promote efficiency in the market and thus to prevent market distortions. The objective of intellectual property law is to protect innovative ideas in the form of inventions which create private monopoly rights for a limited period of time (20 years) under the TRIPs Agreement. The general perception is that there are inherent tensions between IPRs and competition, because IPRs protection gives monopoly rights and competition law fights against monopoly in the market. But monopoly per se in the market is not anti-competitive in nature, but abuse of monopoly is considered as anti-competitive [3].

The technological advances and patent protection laws leads to more cases on abuse of monopoly rights, especially in the high technology areas where it requires more fundamental research on the interplay between intellectual property and competition law. The number of Intellectual Property Rights (IPRs) related competition cases has been increasing in the recent past especially in countries like the US and the EU.

To understand the ground reality of the difficulties in applying competition law and intellectual property law, it is essential to look into the systems of various countries, their practices and provisions as they deal with competition and intellectual property. While developed countries like the US adopted legislations on competition much earlier and have been pursuing a new agenda, the newly opened economies like India are experimenting with the new legislations. There are lessons to be learned and experiences to be shared. This paper analyzes the legislations in the US and EU and compares it with the Indian context in order to draw lessons for a developing country like India.

\section{US Laws on Competition and IP Interface}

'Antitrust law in general and the Sherman Act in particular are the Magna Carta of free enterprise. They are as important to the preservation of economic freedom and free enterprise system as the Bill of Rights is to the protection of our fundamental personal freedoms.' 5 The roots of competition law in the US can be traced back to the Sherman Act of 1890. The US terminology for competition is 'antitrust' - the law enacted to curb the monopolistic activities of trusts formed to carry out various trade activities during that time. The objective of the Act was to oppose the combination of entities and their activities that cause harm competition in the market. Title 15, Chapter 1 of United States Code (Sherman Act), prohibited monopolization and conspiracies which restrain trade, and prescribed imprisonment and fines for violations. Section. 2 of the Sherman Act prohibited every contract or conspiracy in restraint of trade between the states or with foreign countries and treated it as a felony and imposed heavy punishments on

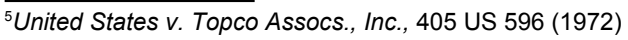

defaulters ${ }^{6}$. This provision in conjunction with Section 7 of the Clayton Act which prohibits mergers or acquisitions which may tend to lessen competition $^{7}$.

Section 2 of the Sherman Act has two elements: (1) the possession of monopoly power in the relevant market, ${ }^{8}$ and (2) the willful acquisition or maintenance of the power as distinguished from growth or development as a consequence of a superior product, business acumen or historic accident. ${ }^{9}$ Section 13 prohibits discrimination in prices while selling the same product to different customers with the view to lessen competition and to curb the tendency to create a monopoly in any line of commerce, to do away with injury, destruction, and to prevent competition or any person engaged in commerce, in the course of such commerce, knowingly to induce or receive discrimination in price. The Sherman Act contained a blanket prohibition of all contracts and combinations in the form of a trust in restraint of trade for commerce among several states or with foreign nations. ${ }^{10}$ In addition, The Federal Trade Commission (FTC) Act and Robinson Patman Act may also be used to find out economic activities prohibited and have a likely antitrust consequence.

Chief Justice White in Standard Oil Co. of New Jersey v. United States, ${ }^{11}$ observed that:

the merely generic enumeration which the statute makes of the acts to reach it refers and the absence of any definition of restraint of trade as used in the statute leaves room for but one conclusion, which is, that it was expressly designed not to unduly limit the application of the act by the precise definition, but while clearly fixing this standard, that is by definition the ulterior boundaries which could not be transgressed with impunity, to leave it to be determined by the light of reason, gated by the principle of law and the duty to apply and enforce the public policy embodied in the statute, every given case whether any particular act of contract was between the contemplation of the statute.

In this case the US Supreme Court found that Standard Oil Company was guilty of monopolising the petroleum industry through a series of anti-competitive and abusive actions.

In Chicago Board of Trade v. United States, ${ }^{12}$ Brandies J. observed that every trade association and board of trade imposes some restraint upon the conduct of its members. He explained the rule of reason in the following words: 'the true test of legality is whether the restraint imposed is such as merely regulates and perhaps thereby promotes competition or whether it is such as may suppress or even destroy competition.' This therefore puts a charge on the court to determine what constitutes restraint of trade in each and every case according to the nature of the restraint and its effect on the market. This particular doctrine developed by the US Supreme Court has always taken the view that the court can in line with economic progress of the country [4].

Later the Clayton Act of 1914 was passed to supplement the Sherman Act 1890 which prohibits some behaviour in relation to prices, exclusivity and mergers. S.4 of the Clayton Act provides for damage

\footnotetext{
${ }^{6}$ The monetary punishments are of a fine not exceeding $\$ 100,000,000$ if a corporation, or, if any other person, $\$ 1,000,000$, or by imprisonment not exceeding 10 years, or by both said punishments.

15 USC S.18

${ }^{8}$ Aspen Skiing Co. v. Aspen Highlands Skiing Corp., 472 U.S. 585, 597 (1985) Intergraph Corp. v. Intel Corp., 195 F.3d 1346, 1353 (Fed. Cir. 1999).

${ }^{9}$ U.S. v. Grinnell, 384 U.S. 563, 570-71 (1966); see also Aspen Skiing Co., 472 U.S. at $595-96$

${ }^{10}$ Section 1, Sherman Act, 1890

${ }^{11} 221$ US 1 (1911)

${ }^{12}(1918) 246$ U.S. 231
} 
provisions of the antitrust laws. 15 USC. S.15 (a) permits "any person... injured in his business or property by reason of anything forbidden in the antitrust laws to sue therefore and to recover threefold the damages by him sustained, and the cost of suit, including a reasonable attorney's fees." The merger guidelines issued by the Department of Justice offer an indication of the ways in which mergers and acquisitions will be analyzed by the antitrust Division and the FTC. ${ }^{13}$ This Act added other activities to the list to be designated as 'prohibited'. These include:

- Price discrimination between different purchasers, if such discrimination tends to create a monopoly,

- $\quad$ Exclusive dealing agreements,

- Tying arrangements, and

- Mergers and acquisitions that substantially reduce market competition.

It is pertinent to note that in the case of United States $v$. TransMissouri Freight Association, the US Supreme Court held that price fixing agreements were illegal ${ }^{14}$ and the US Court of Appeals of the Sixth Circuit further confirmed this position in Addyston Pipe and Steel Co. $v$. United States,${ }^{15}$ when it stated that that price fixing cannot be justified in any given circumstance. The prohibition of price agreements are strongly dealt with under competition laws all over the world. Further in Dr. Miles Medical Co. v. John D. Park and Sons, the US Supreme Court maintained that resale price maintenance between manufacturer and distributor is per se illegal. ${ }^{16}$ The Standard Oil Co., ${ }^{17}$ case and American Tobacco Company case $^{18}$ further strengthened this position. In the latter case, the issue in question was a combination of trade and an attempt to monopolize the business of tobacco in interstate commerce within the prohibitions of the Sherman Act of 1890 .

Meanwhile the merging of companies into a single firm continued unabated under the Sherman Act. To curb this menace, the Clayton Act of 1914, Section 7A added to the Act by 1976 amendment, which prohibits mergers and price discrimination targeted to distort markets and capable of reducing competition. In Applachian Coals v. US, ${ }^{19}$ the US Supreme Court took the view that the incorporation of a company for the marketing of coal, by a considerable number of producers doesn't violate the anti-trust laws. The Court observed that the mere fact that the parties to a combination eliminate competition among themselves is not enough to condemn it. These decisions should be viewed from the background of World War II and the 1929 recession in the world markets. Gilbert and Shapiro talks about the trade off and IP - Antitrust conflict and "Nine no-nos" in the intellectual property licensing which covers most of the conflicting areas ${ }^{20}$. All the nine areas are used by the monopoly right holders to extend their monopoly term indefinitely or to get control over the incremental innovations on the existing patents. In the 1980s the Antitrust Division started questioning the "nine no nos" theory and adopted "rule of reason approach" in patent licensing. Finally in 1995, the Justice Department come out with "Antitrust Guidelines for the Licensing of Intellectual Property." The

${ }^{13}$ Antitrust guidelines were issued in 1962 and revised in 1982, 1984, 1992 and 1997.

${ }^{14}$ United States v. Trans-Missouri Freight Association, 166 U.S. 290 (1897)

${ }^{15} 85$ F. 271 (6 $6^{\text {th }}$ Cir. 1898)

${ }^{16}$ Dr. Miles Medical Co. v. John D. Park and Sons, 220 U.S. 373 (1911)

${ }^{17}$ Standard Oil Co. of New Jersey v. United States, 221 U.S. 1 (1911)

${ }^{18}$ American Tobacco Company, 221 U.S. 106 (1911)

${ }^{19} 288$ U.S. 344 (1933)

${ }^{20}$ Richard Gilbert and Carl Shapiro, Anti-trust Issue in the Licensing of Intellectual

Property: The Nine No-nos Meet the Nineties, Brooking Papers on Micro

Economics, conflicting areas are further explained under different heads for better understanding.

\section{Abuse of dominant position}

In the legal parlance dominant position is "a position of economic strength enjoyed by the enterprise which enables it to prevent effective competition being maintained on the relevant market by giving it the power to behave to an appreciable extent independently of its competitors, customers and ultimately of its consumers." ${ }^{21}$ The concept of 'Abuse of dominant position' provided in Section 2 of the Sherman Act 1890 aims at preventing anti-competitive, exclusionary behaviour directed at competitors.

\section{Refusal to deal}

The US antitrust law prohibits certain business practices adversely affecting competition in the market. Section 1 of the Sherman Act prohibits concerted effort of persons entering into agreement, contracts, and combinations in restraint of trade. But an individual person can refuse to deal with another without violating the first provision. This anti-trust principle was prevalent from 1919 with the decision of the US Supreme Court in Colgate case ${ }^{22}$. After this case, the practice is known as "Colgate doctrine." This doctrine permits a non-monopolistic manufacturer to choose the parties whom he wants to deal. But there is a possibility of resale price maintenance (RPM) by such monopolist and ultimately refuses to deal with dealers those who refuse to follow the price maintenance. In this background the Supreme Court revisited the "Colgate Doctrine" in Russel Stover Candies Inc. v. FTC. ${ }^{23}$ This decision led to the "rule of reason" standard in judging RPM policies and gradually abolishing the "Colgate doctrine [5]. It is interesting to look into the patent protection scenario where the patent holder refuses to deal in the background of antitrust provisions.

The US provision on the subject is contained in 35 U.S.C. $\$ 271$ (d) which provides that:

(d) No patent owner otherwise entitled to relief for infringement or contributory infringement of a patent shall be denied relief or deemed guilty of misuse or illegal extension of the patent right by reason of his having done one or more of the following:

- Derived revenue from acts which if performed by another without his consent would constitute contributory infringement of the patent.

- Licensed or authorized another to perform acts which if performed without his consent would constitute contributory infringement of the patent.

- Sought to enforce his patent rights against infringement or contributory infringement.

- Refused to license or use any rights to the patent. (Or)

- Conditioned the license of any rights to the patent or the sale of the patented product on the acquisition of a license to rights in another patent or purchase of a separate product, unless, in view of the circumstances, the patent owner has market power in the relevant market for the patent or patented product on which the license or sale is conditioned.

\footnotetext{
${ }^{21}$ United Brands Company and United Brands Continental BV v. Commission of the European Communities, [1978] EUECJ C-27/76 (14 February 1978).

${ }^{22}$ United States v. Colgate \& Co., 250 U.S. 300 (1919)

23718 F2.d 256 ( $7^{\text {th }}$ Circuit, 1983)
} 
In A\&M Records, Inc. v. Napster, Inc., ${ }^{24}$ case, it was held that one of the characteristic of copyright is the right to curb the development of a derivative market by refusing to license copyright. Although it is likely that unilateral refusal to license copyright may give rise to misuse of claim but the broad assumption is that the desire to exclude is a presumptively valid business justification. Likewise, unilateral refusal to license diagnostic software is not an antitrust violation. ${ }^{25}$ However, in Blonder Tongue Labs. v. Univ. Illinois Found., it was held that 'the patentee has the power to refuse a license but it does not enable him to enlarge the monopoly of the patent by the expedient of attaching conditions to its use.'26 In Eastman Kodak Co. v. Image Technical Services, Inc., also it was held that "power gained through some natural and legal advantage such as a patent, copyright, or business acumen can give rise to liability if 'a seller exploits his dominant position in one market to expand his empire into the next'."

In copyright cases also, the court reaffirmed the right of intellectual property owners and held that 'Nothing in the copyright statutes would prevent an author from hoarding all of his works during the term of the copyright. In fact, this Court has held that a copyright owner has the capacity arbitrarily to refuse to license one who seeks to exploit the work ${ }^{27}$.

\section{Tying agreements}

Tying, Tie-ins, sales on condition are some of the common practices which violate the anti-trust law in the US. In tying arrangements a seller agrees to sell a highly usable product or service only on the condition that the buyer also purchase a less important or marketable product or service, irrespective of the fact whether the buyer wants the second product or not. Tying is unlawful under section 1 of the Sherman Act and section 3 of the Clayton Act. In the US and some other countries, intellectual property is considered on the same footing as other forms of property and the owner need not license it to third parties. ${ }^{28}$ In some cases there is allegation of refusal to license with tying. The Tele - Direct case in Canada is the most discussed tie-in-selling case. ${ }^{29}$ In this case it was alleged that selective refusals by the respondent to license its trademark constituted an abuse of its dominant position. It was finally held that Tele-directs refusal to license its trademark was well within its legal bounds.

Another noteworthy case is the Eastman Kodak case wherein it was stated that 'A tying arrangement - i.e., an agreement by a party to sell one product on the condition that the buyer also purchases a different (or tied) product, or at least agrees that he will not purchase that product from any other supplier-violates $₫ 1$ of the Sherman Act, only if the seller has appreciable economic power in the tying product market. ${ }^{30}$ Further if anybody wants to prove an illegal tying violation, he must prove:

- That the seller conditioned the sale of one product or service on the purchase of a second;

- That the two products or services are in fact separate and not parts of a single product or service;

\footnotetext{
${ }^{24} 239$ F.3d 1004, 1026-27 \& n.8 (9th Cir. 2001)

${ }^{25}$ Advanced Computer Servs. of Mich. v. MAl Sys. Corp., 845 F. Supp. 356, 369 (E.D.Va 1994)

${ }^{26} 402$ U.S. 313, $344(1971)$

${ }^{27}$ Stewart v. Abend, 495 U.S. 207, 228-29 (1990)

${ }^{28}$ See Correa, http://www.iprsonline.org/resources/docs/corea_Oct07.pdf, visited on 11.11.2010.

${ }^{29}$ Canada Director of Investigation and Research v. Tele-direct (Publications) Inc., ${ }^{30}$ Eastman Kodak v. Image Technical Services Inc. (90-1029), 504 U.S. 451 (1992)
}

- That the seller has sufficient power in the market for the tying product to enforce the tie-in; and

- That the tie-in affected a substantial amount of commerce. ${ }^{31}$

In the Paramount Pictures case, the court said that the ability of a licensee to license one or more items of intellectual property on the licensee's purchase of another item of intellectual property or a good or a service has been held in some cases to constitute illegal tying. ${ }^{32}$ The court also held that a copyright may no more be used than a patent to deter competition between rivals in the exploitation of their licenses. ${ }^{33}$ The licensing of multiple items of intellectual property in a single license or a group of licenses may be in the form of a tying arrangement if the licensing of one product is conditioned upon the acceptance of a license of another. Hence, theoretically a tying agreement can lead to a rule of reason violation if it can prove that the tie-in fostered sufficient anti-competitive impact in the tied product market. ${ }^{34}$

Later in International Salt Co., Inc. v. United States, ${ }^{35}$ the US Supreme Court held that tie-in-sales where a producer sells a product or service only if the customer also purchases another product or service of the same producer is per se prohibited under the law. The anti-trust laws always encourage competition in the market vis-a-vis - innovation, efficiency, and low pricing. Anti-trust laws discourage monopolies that resort to unfair or predatory methods and those who seek to use monopoly power in markets to obtain such power in other markets. The inherent tension between anti-trust law and intellectual property law is that, anti-trust law tries to punish those who seek or maintain monopolies, but intellectual property law permits limited monopoly for a limited period of time, as an incentive to the innovator. The result is an inevitable clash and tension between anti-trust and intellectual property law.

The US Court of Appeals of Second Circuit in the matter of SCM Corp. v. Xerox Corp. Opined that 'while the anti-trust laws proscribe unreasonable restraints of competition, the patent laws reward the inventor with a temporary monopoly that insulates him from competition....the patent and competition laws necessarily clash. ${ }^{36} \mathrm{On}$ the other hand, the current thinking is summarized quite well in the Federal Circuit 's 1990 opinion in Atari Games Corp. v. Nintendo of America, Inc., in which the Federal Circuit stated that: 'the aims and objectives of patent and antitrust laws may seem, at first glance, wholly at odds. However, the two bodies of law are complementary, as both are aimed at encouraging innovation, industry and competition. ${ }^{37}$

\section{Exclusive licenses}

An exclusive license provides the licensee the promise that the licensor will not practice under the patent, and that the licensor will not grant licenses to any other parties. Exclusive licenses occur when a license prevents the licensee from licensing, selling, distributing, or using competing technologies. ${ }^{38}$ Two things must be taken into consideration for evaluating the competition in the market:

\footnotetext{
${ }^{31}$ /bid. p.451, 463

${ }^{32}$ United States v. Paramount Pictures, Inc., 334 U.S. 131 (1948)

${ }^{33}$ Ibid. P. 334 U. S. 144

${ }^{34}$ White Motor Co. v. United States, 372 US 253, 262-263; Northern Pac. Ry. Co. v. United States, US.1, 6-7 (1958).

35332 U.S. 392 (1947)

${ }^{36} 645$ F.2d 1195 (2nd Cir. 1981)

${ }^{37}$ Atari Games Corp. v. Nintendo of America Inc. 897 F. 2d 1572 (Fed. Cir. 1990) (citing Loctite Corp. v. Ultraseal Ltd., 781 F.2d 861, 876-77, 228 U.S.P.Q. (BNA) 90, 100-01 (Fed Cir. 1985))

${ }^{38}$ Tampa Electric Co. v. Nashville Coal Co., 365 US 320 (361)
} 
- Whether it promotes the exploitation and development of the licensor's technology and

- Whether it anti-competitively forecloses the exploitation and development of or otherwise constrains competition among competing technologies.

If the exclusive dealing arrangement has an anti-competitive effect, it will be evaluated to understand the extent to which the restraint encourages licensees to develop and market the licensed technology, increases licensor's incentives to develop or refines the licensed technology or otherwise increases competition and enhances output in a relevant market.

In Federal Trade Comm'n v. Mylan Lab., Inc. ${ }^{39}$ Federal Trade Commission or the FTC filed a complaint against Mylan Laboratories, the second largest generic drug manufacturer, along with three other companies in the generic drug industry. These companies were charged with restraint of trade, monopolization, and conspiracy to monopolize the markets for generic lorazepam and clorazepate tablets two widelyused anti-anxiety drugs for which over 21 million prescriptions are written in the US each year.

Mylan had sought and obtained ten-year exclusive licenses for Profarmaco's Drug Master File (DMFs) for the active pharmaceutical ingredient (APIs) for both lorazepam and clorazepate. Thus Mylan was able to prevent other generic drug manufacturers from gaining access to the raw materials needed to market competing products. In return for these exclusive licenses, Mylan offered to pay Profarmaco, Cambrex, and Gyma, a percentage of Mylan's gross profits on sales of lorazepam and clorazepate tablets. Mylan also sought a similar ten-year exclusive license from SST Corporation.Shortly after Mylan obtained exclusive licenses from Profarmaco and Gyma, Mylan significantly raised its prices for generic clorazepate and lorazepam tablets. However, ultimately the FTC got a cease and desist order against Mylan as well as sought restitution to the tune of $\$ 120$ million. The same rule was followed in the famous Microsoft Case.

\section{Patent pooling and mergers}

Patent pool $^{40}$ in licensing is regarded as a price fixing cartel. Cross licensing and pooling are arrangements by means of agreements, by two or more owners of different items of intellectual property to license it to one another or to grant it to third parties. Refusal to deal is also considered as anti-competitive. ${ }^{41}$

One of the famous cases of pooling is the case relating to Digital Versatile Disc (DVD) technology. The pool was proposed by eight electronics firms and Columbia University. The pool concerned MPEG2 , a video data storage compression standard. Video compression allows savings in data storage and transmission space, a technology used with DVD production. The participants proposed to pool 27 patents held by numerous and different patentees. The pool planned to issue a blanket, non-exclusive license at a royalty rate agreed upon by the licensors. The second pool was proposed by Philips, Sony, and Pioneer and concerned a pool of patents necessary to comply with the standards for the production of DVDs and DVD players. In each case, the Department of Justice (DOJ) declined to initiate an enforcement action based on the patent pool descriptions that were provided by the parties. The DOJ

${ }^{39}$ No. 1:98CV03114 (TFH) (D.D.C. amended complaint filed under seal Feb. 8, 1999)

${ }^{40} \mathrm{Patent} \mathrm{Pool}$ is an agreement among patent owners to license a set of their patents to one another or to third parties.

${ }^{41} /$ mage Technical Services v. Eastman Kodak Company F. 3d 1195 (9 ${ }^{\text {th }}$ Circuit, 1997) concluded that the pool included only complementary, not competing patents, each of which was deemed essential to compliance with the MPEG-2 standards. The patent holders were not pooling competing technologies, but rather assembling complementary components of a single technology. The pool also promised equal access and 'nonexclusive' licenses. Thus it was held that patent pooling doesn't prevent competitors from developing alternate technologies and in fact the pool has significant efficiencies. In this case the DOJ seemed to support the pooling due to the nature of the technology and its advantages. However, the story is not the same in all cases.

In 1998, the FTC announced charges against Summit Technology, Inc. and VISX, Inc. regarding their pooling of patents related to photorefractive keratectomy or PRK. ${ }^{42}$ This is a form of eye surgery that uses lasers to reshape the cornea and frees many people from the need to wear glasses or contact lenses. Summit and VISX were the only firms with Food and Drug Administration (FDA) approval to market PRK equipment.

Summit and VISX licensed most of their PRK patents to a shell entity named Pillar Point Partnership. This partnership then licensed the full portfolio of patents back to Summit and VISX, and only to Summit and VISX. Summit and VISX sold or leased PRK equipment to eye doctors and sub-licensed the doctors to perform PRK procedures. The patent pooling arrangement required Summit and VISX to pay the Partnership a $\$ 250$ fee each time a PRK procedure was performed. Summit and VISX, in turn, charged each of their respective sub licensees a $\$ 250$ per-procedure fee. Neither Summit nor VISX had an incentive to reduce this fee because the patent pooling agreement obligated each firm to pay this amount to the pool.

The Commission found that the pooling had completely eliminated competition from the market and Summit and VISX that otherwise would have existed in markets for PRK equipment, licensing of patents, and licensing of technology related to the procedure, did not need to do so. Second, the exclusive nature of the agreement restricted the access of other firms to PRK technology by reducing each party's incentives to license PRK technology to other firms. Finally the companies agreed to discontinue the pooling.

Another common form of anti-competitive practice is the 'innovation market' where two companies join together for a Research and Development (R\&D) collaboration and finally only one company comes out with a product to the market leading to exploitation while creating a monopoly on the market. Sometimes even collaborators though they own many patents do not come out with any product in the market. In the CIBA-Geigy case, ${ }^{43}$ the Federal Trade Commission (FTC) challenged the merger between CIBA-Geigy and Sandoz, two Swiss pharmaceutical companies with Novartis AG. Both companies had patents on genetic elements that could produce drugs for several diseases, but none of the companies had produced a marketable product out of those patents.

In the first market, for overall gene therapy, the Commission alleged that Ciba and Sandoz controlled the key intellectual property rights necessary to commercialize gene therapy products. ${ }^{44}$ For each of the four specific gene therapy markets, the Commission asserted that the relevant market was highly concentrated and that Ciba and Sandoz were the two leading commercial developers of the gene therapy product. ${ }^{45}$ Moreover, entry into the gene therapy markets was difficult

\footnotetext{
${ }^{42}$ In re Summit Tech., Inc. \& VISX, Inc., No. 9286 (FTC Mar. 24, 1998) (complaint) 43123 FTC 842 (1997)

${ }^{44} /$ bid. p. 846

${ }^{45}$ Ibid. p. 847
} 
and time-consuming because any entrant would need patent rights, significant human and capital resources, and FDA approvals. ${ }^{46}$ Novartis was required to grant non-exclusive licenses to companies who wanted to develop and commercialize gene therapy products. Depending on the patent, Novartis was charging royalties from the licensee for cross licenses as well.

The mergers of big companies raise anti-trust concerns because they tend to block further research in the area and in the development downstream technologies especially in products like drugs. This severely affects the competition in the market.

The Glaxo - Welcome ${ }^{47}$ merger in 1995was another one in the merger-competition issue discussed elaborately. The FTC found that the companies were competitors in the highly concentrated market for a specific type of advancement in migraine treatment. The merger would eliminate competition in research as well as products in the market. Later on, the companies come to an agreement with the Commission. The agreement required the combined firm to divest Welcome's assets related to the research and development of the migraine remedy. Those assets were patents, technology, manufacturing information, testing data, research materials, and customer lists. ${ }^{48}$ There is every possibility of reducing competition in the market whenever there is a merger in the market between competitors.

The Robinson Patman Act (15 USC S.13) prohibits price discrimination. It stipulates that two or more purchasers of the same commodity from the same seller must be charged identical prices. This provision prohibits unjustified price discrimination. Such sales must be in the interstate commerce of like commodities with like grade and quality within the US not to services. ${ }^{49}$

The Federal Trade Commission Act, (15 USC S.45) prohibits unfair methods of competition and unfair or deceptive acts in commerce with foreign nations. ${ }^{50}$ The unfair conduct must have a direct, substantial and reasonably foreseeable effect on the foreign commerce in question..$^{51}$

\section{EU regulation on competition}

The Rome Treaty establishing the European Economic Community (EEC and presently the group of EU countries) is basically meant for more competition in the market [6]. Competition is being regarded as a means of keeping costs and prices down and also to have more quality products in the market which stimulate innovation and more technological advancements [7]. Article 81 and 82 are the competition provisions in the Treaty that governs the potential use and abuse of intellectual property rights. Article 81 of the Treaty bars agreement that adversely affect trade between member states through the restriction of competition. Article 82 of the Treaty prohibits the abuses associated with those who have already achieved dominant positions in the market. Although market dominance per-say is not prohibited under the Treaty, abuse of market dominance is prohibited. Both these provisions facilitate free movement of goods and services throughout the EU member states. Article 82 specifically governs the licensing of intellectual property rights.

The Council Regulation 17, implementing Article 81 and 82 which was enforced from 1962 was replaced by Council Regulation 1/2003. ${ }^{52}$

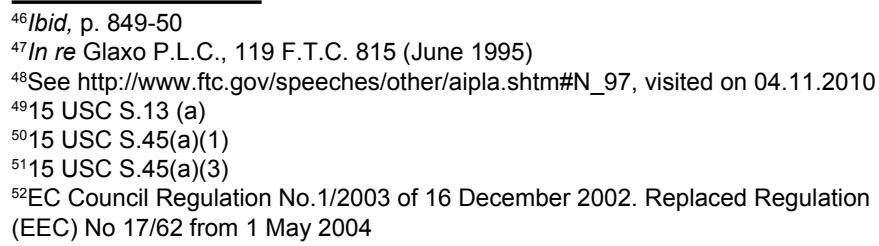

It was the first regulation to modernize the competition law in the EU. These provisions were replaced by Articles 101 and 102 respectively. ${ }^{53}$ Article 102 of EU regulation and Section 2 of Sherman Act are similar. Both provisions are meant to prohibit unilateral conduct which influences a certain market, and have the effect of impairing trade between member States. But the European competition law does not punish conduct aimed at obtaining a dominant position. A unilateral abuse of dominant position is only actionable under the EU law. Both laws concentrate on "consumer welfare" prescription and as an important goal of competition policy.

The role of competition policy in the EU treaty is to integrate the markets of member states, i.e. using competition, monopoly and merger legislation to prevent anti-competitive practices used by companies. Articles 101 and 102 of the EU treaty recognize that competition has a basic mechanism of the market economy and encourages companies to produce products that the consumer wants. ${ }^{54}$ It encourages innovation and pushes down prices in the market. In order to be an effective competition in the market, the suppliers must be independent and without collusive association between them. Article 101 (earlier 81) of the Treaty prohibits agreement between two or more firms that restrict competition. It includes cartel between competitors, price-fixing and market sharing agreements. It prohibits the following specific actions under the provision. They are:

- To directly or indirectly fix purchase or selling prices or any other trading conditions;

- Limit or control production, markets, technical development, or investment;

- Share markets or source of supply;

- Apply dissimilar conditions to equivalent transactions with other trading parties, thereby placing them at a competitive disadvantage;

- Make the conclusion of contracts subject to acceptance by the other parties of supplementary obligations which, by their major or according to commercial usage, have no connection with the subject of such contracts.

Article 102 prohibits abuse of dominant position like predatory pricing strategies of companies to eliminate competitors from the market. In addition to these treaty provisions the European commission regulation on specific areas like nerds of control is also in place.

It specifically prohibits abuses like:

- $\quad$ Directly or indirectly imposing unfair purchase or selling prices or other unfair trading conditions;

- Limiting production, market is in whose behalf they have which is sadly diminished from a lack in the or technical development to the prejudice of consumers;

- Applying dissimilar conditions to equivalent transactions with other trading parties, thereby placing them at a competitive disadvantage;

- Making the conclusion of contracts subject to acceptance by the other parties of supplementary obligations which, by their nature or according to commercial usage, have no connection with the subject of such contracts.

\footnotetext{
${ }^{53}$ Official Journal 115, 09/05/2008 P. 0088 - 0089

${ }^{54}$ Antitrust
} 
In accordance with the case-law, it is not per se illegal for an undertaking to be in a dominant position and such a dominant undertaking is entitled to compete on the merits. However, the undertaking concerned has a special responsibility not to allow its conduct to impair genuine undistorted competition on the common market. Article 102 is the legal basis for a crucial component of competition policy and its effective enforcement helps markets to work better for the benefit of businesses and consumers. This is particularly important in the context of the wider objective of achieving an integrated internal market. ${ }^{55}$

Action against cartel in the EU is a specific anti-trust enforcement. A cartel is a group of independent companies which join together to fix prices, to limit production or to share markets or customers between them. The cartel member's action in the market reduces competition and incentives for constant innovation of products. The objective of all categories of prohibitions is that markets function properly and that consumers benefit from the efficiency and productivity which result from effective competition between undertakings.

The European Commission has the primary role in the enforcement of community law. It consists of 20 commissioners nominated by the member states, and accepted en masse by the European Parliament. Administratively, the commission is divided into Directorate Generals with Director General IV having responsibility for competition policy. Appeals against the decisions of the commission can be made to the Court of First Instance (CFI). The appeals from the Court of First Instance lie in the European Court of Justice on points of law within two months of the CFI notifying parties of its decisions. ${ }^{56}$

\section{Abuse of dominant position}

The assessment of whether an undertaking is in a dominant position and the degree of market power it holds is a first step in the application of Article 102. The following specific factors will be considered for the determination of the dominant position:

- Constraints imposed by the existing supplies from, and the position on the market of, actual competitors (the mark-up position of the dominant undertaking and its competitors); or directly or indirectly imposing unfair prices or other unfair trading conditions;

- Constraints imposed by the credible threat of future expansion by actual commentators or entry by potential competitors (expansion and entry); or limiting production or development to the prejudice of consumers;

- Constraints imposed by the bargaining strength of the undertaking's customers (countervailing buyer power); or unequal treatment of trading parties, thereby placing some at a competitive disadvantage;

- The market share and the turnover of a certain company can be strong indicators that a certain company has reached a dominant position.

- Making use of tying contracts, hence, forcing unnecessary supplementary obligations on customers. Of course, other price or non-price strategies may be considered an abuse as well.

${ }^{55}$ Communication from the Commission - Guidance on the Commission's enforcement priorities in applying Article 82 of the EC Treaty to abusive exclusionary conduct by dominant undertakings (Text with EEA relevance)

${ }^{56}$ Article 31 of the Treaty Establishing the European Community
Dominant position is a position of economic strength that enables a firm to prevent effective competition in the relevant market. If a dominant firm in the market use such practices, it is considered as anticompetitive. In a dominant position, the large firm has a substantial or reasonably large market power. Market share of the firm is crucial in the determination of dominance.

The judicial practice of the European Court of Justice (ECJ) followed a similar line of argument in the cases United Brands $(1978)^{57}$ Hoffmann-La Roche (1979), ${ }^{58}$ and Michelin (1983). ${ }^{59}$ Market dominance can take two basic forms. In one form, an undertaking actively violates the fair competition on the relevant market. In the other, the current economic situation places the monitored company in a position in which it does not have to pay attention to the other market actors when forming its own behaviour on the relevant market. ${ }^{60}$ In its United Brands decision, the ECJ gave a definition of the dominant position that corresponds to the latter alternative and stresses the independent formation of business conduct. ${ }^{61}$ In Hoffmann-La Roche, it was held that "position of economic strength enjoyed by an undertaking which enables it to prevent effective competition being maintained on the relevant market by affording it the power to behave to an appreciable extent independently of its competitors, its customers and ultimately of the consumers." The court viewed that very large market shares are in them, save in exceptional circumstances, evidence for dominance. ${ }^{62}$

Dominant position in the market as such is not prohibited but the smaller companies have an opportunity to grow. A company that has reached dominant position in the relevant market must respect free competition in the market. The Microsoft case is the recent one on abuse of dominant position and refusal to supply essential information to third parties and tying of products..$^{63}$

In Volvo v. Veng, the European Court of Justice considered the question of whether refusal to license an intellectual property right could be considered abusive. ${ }^{64}$ Volvo was the owner of a digested design of the front wings of the automobile. Veng, an importer of unlicensed spare parts for Volvo cars, wanted to use Article 82 as a defence in a claim from Volvo that it had infringed its UK registered design rights. Volvo contended that Veng was infringing their exclusive right to manufacture and sell the parts. The court conceded it, prima facie as an abuse of such dominant position for such a manufacturer to refuse to licence others to supply such body panels, even where they are willing to pay a reasonable royalty for all articles sold under the licence. The court held that:

The refusal by the proprietor of a registered design in respect of body panels to grant to third parties, even in return for reasonable royalties, a licence for the supply of parts incorporating the design cannot in itself be regarded as an abuse of a dominant position within the meaning of Article 82.

However, the exercise of such an exclusive right by the proprietor of a registered design in respect of car body panels may be prohibited by Article 86 if it involves, on the part of an undertaking holding a

\footnotetext{
${ }^{57}$ Case C-27/67, United Brands Co. \& United Brands Cont'l BV v. Comm'n, 1978 E.C.R 207

${ }^{58}$ Case C-85/76, Hoffmann-La Roche \& Co. AG v. Comm'n, 1979 E.C.R. 461 ${ }^{59}$ Case C-322/81, NV Nederlandsche Banden Industrie Michelin v. Comm'n, 1983 E.C.R 3461

${ }^{60}$ Thomas Eilmansberger et al., Materielles Europarecht [Substantive European Law] 246 (2008)

${ }^{61}$ Case C-27/67, supra note 3 , at $63-66$

${ }^{62}$ Case No. $85 / 76$

${ }^{63}$ Case T-201/04, Microsoft v. Comm'n, 2007 ECR II-1491

${ }^{64} A B$ Volvo v Erik Veng (UK) Ltd (1988) EUECJ C-238/87
} 
dominant position, certain abusive conduct such as the arbitrary refusal to supply spare parts to independent repairers, the fixing of prices for spare parts at an unfair level or a decision no longer to produce spare parts for a particular model even though many cars of that model are still in circulation, provided that such conduct is liable to affect trade between Member States. ${ }^{65}$

The courts observation came on the factual back ground that Veng had no intention to innovate. The judgment notes that the refusal to supply can be an abuse in some circumstances, even though it is not an abuse by itself. However, under article 82 if it was found that the right holder abuses his right by arbitrary refusal to license will be considered as an abuse of dominant position.

In the Magill case ${ }^{66}$ it was held that individual property ownership and refusal to license may constitute an abuse and breach of competition laws. The case involved a broadcast company's refusal to license program schedules to a publishing company interested in publishing a television guide. In this case Mr.Magill who wanted to publish the listings of three television companies broadcasting in the UK and Ireland in a single weekly. Copyright protection was available for TV listings under UK and Irish law, which is why Magill required a license. Moreover, there was great demand for a publication with advance TV listings. The Commission concluded that the three television companies had abused their own individual dominant positions in relation to their individual TV listings, and required that they provide advance information so that comprehensive TV weekly guided could be published.

The refusal prohibited the entrance of a new product into the market. The European Court of Justice held that compulsory licensing was an appropriate remedy. The court held that mere ownership of intellectual property cannot confer such a dominant position. To this case the European Court of Justice for the first time introduced the doctrine of essential facilities into intellectual property involving competition case. This case had set a precedent for the application of 'compulsory licensing' under Article 82 to IPRs that resulted from substantial investment and risk. ${ }^{67}$

\section{Microsoft Case}

The interface of intellectual property rights and competition law has grown massively, owing to the expansion and strengthening of intellectual property at a large scale. While IP law attributes exclusive control rights to a person over his individual assets, competition law seeks to promote innovation by checking market barriers for the benefit of consumers and encouraging competition among a multiplicity of suppliers of goods, services and technologies.

Two main concerns dominate this IPR/competition law interface is the potential abuse of monopoly pricing, especially in developing countries where effective substitutes to IPR-protected products may not be readily available [8]. Second, competition law seeks to draw a line between permissible business strategies and abuse of IPRs-a line which is often blurred by horizontal agreements, exclusionary licensing restrictions, tie-in agreements, excessive exploitation of IPRs and other selling practices [9]. However, at a conceptual level, the lines are clear. The monopoly rights granted by IPR are not anti-competitive but become so, when exercised beyond their intended scope of exercise.

${ }^{65} \mathrm{http}: / /$ eur-Iex. europa.e u/LexUriServ/LexUriServ. do? uri=CELEX:61987J0238:EN:HTML

${ }^{66}$ Magill TV Guide/ITP, BBC and RTE, [1989] 4 CMLR 757

${ }^{67} \mathrm{http}: / / \mathrm{www}$.indlaw.com/legalfocus/focusdetails.aspx?ID=98
"It is a longstanding topic of debate in economic and legal circles: how to marry the innovation bride and the competition groom"68

Three theoretical bases have been suggested for this reconciliation between IPRs and competition law regimes: ${ }^{9}$

- The view that competition law should only interfere with innovation/IPRs when social welfare is at risk;

- The view that concentration and monopoly markets have the edge over competitive markets in terms of innovation owing to greater capital and resources and

- The view that competition law only concerns itself with consumer welfare when the effects of a proposed action on production and innovation efficiency are neutral or indeterminate [10]. A standard of reasonability has to be applied depending on the individual facts and circumstances of the case.

Microsoft case ${ }^{70}$ decided in $2007^{71}$ in EU is a landmark case on interaction between intellectual property and competition law during the TRIPs regime. ${ }^{72} \mathrm{EU}$ invoked competition rules for consumer welfare against absolute intellectual property protection [11].

The Competition/IPR interface finds expression in Article 82 (present Article 102) of the EC treaty, which Prohibits undertakings with a dominant position on a particular market from conducting themselves in a way which amounts to an abuse of their market power, in circumstances where the abusive conduct is incapable of objective justification.

The case originated with a December 1998 complaint from Sun Microsystems alleging that Microsoft was refusing to supply it with interoperability information necessary to interoperate with Microsoft's dominant PC operating system. The Commission also examined the tying of Microsoft's Windows Media Player to its Windows 2000 version.

The European Commission conducted an investigation pursuant to a complaint received from Sun Microsystems, and decided in March 2004 that this was an abuse of a dominant position under Article $82 .{ }^{73}$ The allegation against Microsoft was that they were refusing to license its software to Sun while at the same time licensing to Sun's competitors.

The court found that Microsoft had abused its dominant position in the PC operating system market by: ${ }^{74}$

- Refusing to supply competitors in the work group server operating system market interface information necessary for their products to interoperate with Windows, and hence to compete viably in the market. The Decision ordered Microsoft to disclose, within 120 days, complete and accurate interface information which would allow rival vendors to interoperate with Windows, and to make that information available on reasonable terms;

\footnotetext{
${ }^{68}$ Mario Monti, European Commissioner for Competition Policy, January 2004 ${ }^{69}$ ABA Section of Antitrust Law, FEDERAL STATUTORY EXEMPTIONS FROM NTITRUST LAW (2007), at 264

${ }^{70} \mathrm{CFI}$, Case T-201/04, Microsoft v. Commission, September 17, 2007

${ }^{71}$ This was against two competition cases decisions of European Commission in European Commission Decision of March 24, 2004 relating to a proceeding unde Article 82 of the EC Treaty (Case COMP/C-3/37.792 Microsoft), OJ 2007 L32/23 ${ }^{72}$ Hans Henrik Lidgard and Tu T. Nguyen, The CFI Microsoft Judgment and TRIPs Competition Flexibilities

${ }^{73} 2007 / 53 / E C$

${ }^{74}$ EUROPA PRESS RELEASES RAPID
} 
- Harming competition through the tying of its separate Windows Media Player product with its Windows PC operating system. The Decision ordered Microsoft to provide, within 90 days, a version of Windows which did not include Windows Media Player.

\section{Commission's Findings}

\section{Interoperability}

"Interoperability", defined by the Commission as 'the ability to exchange information and mutually to use the information which has been exchanged', was derived from an earlier European Council Directive. ${ }^{75}$ As according to Article 82 of the EC Treaty, in order to establish it's violation, Microsoft's monopoly had to be established, thus, after market analysis and position of the Company in the market, it was concluded that Microsoft had a monopoly or quasi monopoly in the market and also concluded that interoperability was a key factor for Microsoft's success in the market. Relying on Volvo v. Veng, ${ }^{76}$ the Commission also determined the legal standard for the abuse which is an "entirety of the circumstances surrounding a specific instance of a refusal to supply." Re-confirming earlier decisions of the ECJ, Court observed that a firm holding a dominant position "has a special responsibility, irrespective of the causes of that position, not to allow its conduct to impair genuine undistorted competition on the common market.' 77

The Commission held that (i) Microsoft's interoperability information was indispensable for non-Microsoft work group server operating systems to be capable of interoperating with the Windows domain architecture; (ii) the refusal to license entailed the risk of the elimination of all competition in the server operating system market; (iii) the refusal prevented other firms to come up with new products in the markets in accordance with customer demand, thus Microsoft's refusal to license was violation of EC competition law.

\section{Media player}

The Commission, after concluding investigation, based on market analysis and evidence, opined that the tying of the Windows Media Player with the Windows 2000 version was anti-competitive and gave a large advantage to Microsoft, in the market for Media Players. This tying was inevitably leading to barriers for fostering future competition and in general it also artificially reduced the incentives of music, film and other media companies, as well software developers and content providers to develop their offerings to competing media players. ${ }^{78}$ The Commission also observed that the protection of existing media technologies through IP rights and the indirect network effects characterising the market translate into entry barriers for developers of other software applications including non-streaming media players.

\section{Refusal to supply}

With regard to workgroup server operating systems and PC operating system market the Commission found that Microsoft had a dominant position. Microsoft has refused to provide Sun with information enabling Sun to design work group server operating

${ }^{75}$ COMMISSION DECISION OF 24.03.2004 RELATING TO A PROCEEDING UNDER ARTICLE 82 OF THE EC TREATY (CASE COMP/C-3/37.792 MICROSOFT), 3-13 (Apr. 21, 2004)

${ }^{76}$ Volvo v. Veng, 1988 E.C.R. 6211

${ }^{77} \mathrm{ECJ}$, Case 322/81, Michelin v. Commission, [1983] ECR 3461, Para 57; CFI, Case T-228/97, Irish Sugar v. Commission, [1999] ECR II-2969, Para 112

${ }^{78}$ Commission Decision of 24 May 2004 Relating to A Proceeding Pursuant To Article 82 Of The EC Treaty and Article 54 Of The EEA Agreement Against Microsoft Corporation systems that can seamlessly integrate in the "Active Directory Domain Architecture," a web of interrelated client PC-to-server and serverto-server protocols that organise Windows work group networks. Microsoft's refusal virtually eliminated complete competition in the relevant market for work group server operating systems with prejudiced the customers and thus Microsoft's refusal constitutes an abuse of a dominant position incompatible with Article 82. Commission does not considered the validity of intellectual property rights hold by Microsoft on these products.

\section{Remedies suggested}

The Commission demanded the disclosure of complete and accurate interface information to non-Microsoft work group servers within 120 days to achieve full interoperability and within 90 days, to offer a version of its Windows PC Operating System, without Windows Media Player. The Commission ordered a Monitoring Trustee to "issue opinions on whether Microsoft has, in a specific instance, failed to comply with this Decision, or on any issue that may be of interest with respect to the effective enforcement of this Decision." Commission has imposed a fine of $€ 497.2$ million. Microsoft appealed to the Court of First Instance and in 2007 the judgment confirmed the findings of the Commission.

The European Commission has imposed a penalty payment of $€ 899$ million $^{79}$ on Microsoft for non-compliance with its obligations under the Commission's March 2004 Decision $^{80}$ prior to 22 October 2007. ${ }^{.1}$ Microsoft was the first company within a period of 50 years to get a penalty for non-compliance with Commission's decision.

Microsoft charged an unreasonable license fee and royalty for providing interoperability information to others. ${ }^{82}$ Any noncompliance with the decision will attract a penalty payment of EUR 2 million per day, calculated from that date, and shall be imposed on Microsoft Corporation. ${ }^{83}$ Ultimately from March 2010, Microsoft decided to give consumers in the European Union the opportunity to choose from a variety of browsers to access and surf the Internet. ${ }^{84}$ Now in the European market consumers have option to use any browser they want to use PCs with windows operating systems for 5 years from March 2010. Thus the long pending battle on competition issues in the high technology field came to an end with lot of unanswered questions on the protection of intellectual property vis-a-vis competition in the market.

\section{Predatory pricing}

Predatory pricing is a practice that the dominant firm charges a price below the cost of production in order to drive the competitors out of the market and injure competition and thereby reap higher profits in the near future. It is a strategy adopted to enhance the market power. In AKZO Chemie BV $v$ Commission of the European Communities, it was observed that "the concept of abuse is an objective concept relating to the behaviour of an undertaking in a dominant position which is such as to influence the structure of a market where, as a result of the very presence of the undertaking in question, the degree of competition is weakened and which, by recourse to methods different from those which condition normal competition in products or services on the

\footnotetext{
${ }^{79} \mathrm{http} / / /$ ec.europa.eu/competition/sectors/ICT/microsoft/implementation.html ${ }^{80}(\mathrm{IP} / 04 / 382)$

${ }^{81}$ Europa Press Release on $27^{\text {th }}$ February 2008, Reference: IP/08/318, Date: 27/02/2008.

${ }^{82}$ Antitrust: Commission ensures compliance with 2004 Decision against Microsoft ${ }^{83}$ IP/05/1695 dated 22/12/2005

${ }^{84}$ Commission welcomes Microsoft's roll-out of web browser choice, Reference: $\mathrm{IP} / 10 / 216$
} 
basis of the transactions of commercial operators, has the effect of hindering the maintenance of the degree of competition still existing in the market or the growth of that competition." ${ }^{85}$ Prices below average total costs, that is to say, fixed costs plus variable costs, but above average variable costs, must be regarded as abusive if they are determined as part of a plan for eliminating a competitor. Such prices can drive from the market undertakings which are perhaps as efficient as the dominant undertaking but which, because of their smaller financial resources, are incapable of withstanding the competition waged against them. with regard to price discrimination it was held that "An undertaking in a dominant position cannot justify sales at a price below its production costs by invoking the need to align its prices on those of another supplier, where it is shown that it has maintained close contacts with that supplier regarding the policy to be pursued in the matter of prices."

In Tetra Pak II, ${ }^{86}$ two tests have been laid down for the determination of predatory pricing. First, prices below average variable costs must always be considered abusive. In such a case, there is no conceivable economic purpose other than the elimination of a competitor, since each item produced and sold entails a loss for the undertaking. Secondly, prices below average total costs but above average variable costs are only to be considered abusive if an intention to eliminate can be shown. In this case it was also clarified that the Article 82 prohibition on predatory pricing was wider than a prohibition on unfair elimination of competitors, and (therefore) that it was not limited to predatory conduct that has a realistic chance of recoupment through higher prices after competitors have been eliminated.

In DP AG (Parcels) case, the European Commission has concluded that Deutsche Post AG (DPAG) has used $€ 572$ million, funds it received from the State to finance its public service mission, to finance an aggressive pricing policy intended to undercut private rivals in the parcel sector between 1994 and 1998. This behaviour breached the key principle according to which companies that receive State funding for services of general interest cannot use these resources to subsidise activities open to competition. In 1994 United Parcel Service (UPS), a private operator specialising in door-to-door parcel services for business customers lodged a complaint accusing DPAG of selling its own parcel delivery service below cost. Hence, public money cannot be used for predatory pricing strategies in an open economy in the name of public services ${ }^{87}$.

In Wanadoo Interactive case, ${ }^{88}$ the Commission found that Wanadoo had infringed Article 82 of the EC Treaty by charging predatory prices for its ADSL services. According to EC case law, two tests can be used to ascertain abuse in the form of predatory pricing: prices below average variable cost are always to be considered abusive; prices below average total cost but above average variable cost are only to be considered abusive if they form part of a plan to eliminate competitors.

The European Court of Justice (ECJ) ${ }^{89}$ confirmed the decision of the Commission that France Télécom cannot rely on any absolute right to align its prices on those of its competitors in order to justify its conduct where such conduct constitutes an abuse of its dominant position. The court held that "abusive practices of Wanadoo restricted market entry

\footnotetext{
${ }^{85}$ Case C-62/86

${ }^{86}$ Tetra Pak International SA v Commission of the European Communities, Case C-333/94

${ }^{87}$ Deutsche Post must repay Euro 572 million used to subsidise price undercutting in commercial parcel services

${ }^{88}$ (Case $T$ - 340/03).

${ }^{89}$ (Case C- 202/07).
}

by competing internet providers, and thus harmed consumers. This is a particularly important confirmation that dominant operators cannot use their market power to stifle competition, and that markets key to the development of the information society should be free to develop competitively." It is clear that if the dominant firm is charging below marginal cost or below average cost, it is considered as predatory in nature.

\section{Tying agreements}

Compelling parties to accept supplementary obligations are prohibited under both US as well as the EU laws. It is considered as a restraint of trade under Article 81(1)(e) or as an abusive conduct under Article 82(d) of the EC Treaty. Two or more competitors negotiate an agreement or simply engage in a concerted practice whereby they agree to make the supply of one product conditional upon the purchase of a second distinct product. Or, it may well happen that in a vertical relation the buyer is required to purchase a certain product as a condition of purchasing another distinct product. In EU most of the cases of tying are associated and developed with abuse of dominant doctrine. The US cases are developed under Section 1 of the Sherman Act and Section 3 of the Clayton Act. Microsoft's tying of the Mediaplayer middleware to Windows operating system - have been framed in the US as violation of section 1 of the Sherman Act. ${ }^{90}$ US cases are filed as violation of both Section 1 and 2 of the Sherman Act as tying cases and attempt to monopolize ${ }^{91}$

\section{Refusal to deal}

Refusal to deal is one of the largest categories of cases faced under Article 102. But it is not per se prohibited under the provision. Only under exceptional circumstances, dominant undertaking will be charged with refusal to deal as an abuse of dominant position. It involves a conduct of a company that has exclusive control of a resource that has exclusive control over the market and its access is indispensable to compete in the market. Refusal to deal may be misused by dominant undertakings to pursue unjustified competitive advantages. There are cases where a dominant firm ceases to supply its competitors, ${ }^{92}$ refuse to access to production facilities (essential facilities) [12], refusal to access to IP rights ${ }^{93}$ and refusal to cooperate in normal industry practices [13]

Article 102 explicitly prohibits dominant undertakings from applying dissimilar conditions to equivalent transactions with other trading parties, thereby placing the latter at a competitive disadvantage. In the United Brands case, ${ }^{94}$ the ECJ held that:

an undertaking in a dominant position for the purpose of marketing a product [...] cannot stop supplying a long-standing customer who abides by regular commercial practice, if the orders placed by that customer are in no way out of the ordinary" [...] "since the refusal to sell would limit markets to the prejudice of consumers and would amount to discrimination which might in the end eliminate a trading party from the relevant market.

The ECJ made it clear that even though sometimes refusal to deal

\footnotetext{
${ }^{90}$ Compare the European Microsoft case, COMP/C-3/37.792, with U.S. v. Microsoft Corporation, 253 F.3d 34 (D.C. Cir. 2001)

${ }^{91}$ Illinois Tool Works Inc. v. independent Ink Inc., 126 S.Ct. 1281 (2006); U.S. v. Microsoft, 87 F. Supp. 2d at 30 (D.D.C. 2000); Eastman Kodak Co. v. Image Technical Services, 112 S.Ct. 2072 (1992); Intergraph Corporation v. Intel Corporation, 195 F.3d 1346 (Fed Cir 1999)

${ }^{92}$ United Brands v. commission, C. $22 / 76,14.02 .1978$, E.C.R, 1978 , p. 207 Commercial Solvents v. Commission, C. 6-7/73, 06.03.1974, E.C.R, 1974, p. 223. ${ }^{93}$ Magill, IMS Health and Microsoft cases

${ }^{94}$ Case C-27/76, United Brands v. Commission [1978] ECR 207, [1978] 1 CMLR 429
} 
may be justified in order to protect a company's commercial interests, but such behaviour could not be tolerated when the actual reason was to strengthen the dominant position.

In a recent case of GSK AEVE, it was upheld the old United Brands dictum, "a dominant undertaking could not stop supplying a long standing customer, unless the orders placed by the customer are out of ordinary course of trade." 95 Subsequently the court rejected the contention of GSK that orders were supplied for parallel import as a valid reason for refusal of supply of orders to contractual retailers in Greece.

In the Bronner case the ECJ developed three conditions to determine whether the refusal to deal constituted an absence of a dominant position. They are:

- The refusal should be likely to eliminate all competition from Bronner in the daily newspaper market;

- The service of the home-delivery system should be indispensable to carrying on the business on the daily newspaper market. Furthermore, the indispensability test requires no actual or potential substitute in existence for that home-delivery scheme; and

- Such refusal cannot be objectively justified.

The court further developed the "indispensability" test. In order to pass indispensability test, the competitor must prove that developing alternatives in an economical way is not possible. The court held that the indispensability test was not proved in this case and the refusal to deal was justified. But the Commission in case of FAG and Case GVG/ $F S$, held that refusal of granting ground duties to third parties by FAG at Frankfurt airport was abuse of dominant position. Here the test of indispensability was passed; it is not possible to duplicate an airport in Frankfurt ${ }^{96}$

\section{Refusal to license}

Refusal to license is another category where the intellectual property law and competition law directly collides. In Bronner ${ }^{97}$ case it was held that:

"In assessing such conflicting interests particular care is required where the goods or services or facilities to which access is demanded represent the fruit of substantial investment. That may be true in particular in relation to refusal to license intellectual property rights. Where such exclusive rights are granted for a limited period that in itself involves a balancing of the interest in free competition with that of providing an incentive for research and development and for creativity, It is therefore with good reason that the Court has held that the refusal to license does not of itself, in the absence of other factors, constitute an abuse." ${ }^{98}$

In CICRA v. Renault case ${ }^{99}$ it was observed that getting IP rights by itself did not constitute an abuse of a dominant position. Only the abusive conduct such as the arbitrary refusal to supply spare parts

${ }^{95}$ Cases C-468-478/06, Sot Lelos kai Sia EE and others vs. GSK AEVE, 16 September 2008, ECR [2008] I-7139

${ }^{96}$ Commission Decision of 14 January 1998 relating to a proceeding under Article 86 of the EC Treaty (IV/34.801 FAG/Flughafen Frankfurt/Main AG), OJ L 72/30 $11 / 03 / 1998$.

${ }^{97}$ Oscar Bronner GmbH \& Co. KG v Mediaprint Zeitungs- und Zeitschriftenverlag $\mathrm{GmbH} \&$ Co. KG, Case C-7/97

${ }^{98}$ Ibid., para. 62

${ }^{99}$ Case 53/87, Consorzio italiano della componentistica di ricambio per autoveicoli and Maxicar v Régie nationale des usines Renault, [1988] ECR 6039. to independent repairers constitutes abuse of dominant position. In Volvo v. Veng, ${ }^{100}$ it was held that "the refusal by that proprietor to grant to third parties, even in return for reasonable royalties, a license for the supply of parts incorporating the design could not in itself be regarded as an abuse of a dominant position.”

In Magill case ${ }^{101}$ on the other hand it was held that the refusal to license the copyrights in question was abusive. In Ladbroke case ${ }^{102}$ also the "indispensability test" was used to identify the abuse of dominant position.

\section{IMS health case}

Generally Article 102 of the EC Treaty does not oblige a dominant company to license its IPRs. Nevertheless, the ECJ held in Magill103 that it was an abuse to prohibit the use of copyrighted information about TV programme timings where this information was essential to allow competition in the market for TV listings magazines.

In Oscar Bronner the ECJ explained that "refusal by the owner of an intellectual property right to grant a license, even if it is the act of an undertaking holding a dominant position, cannot in itself constitute abuse of a dominant position, but that the exercise of an exclusive right by the proprietor may, in exceptional circumstances, involve an abuse"104

The ECJ went on to summarize the "exceptional circumstances" that could render the exercise of an IPR abusive:

- The refusal to license is not objectively justified;

- The IPR to which access is sought is indispensable or essential for carrying on the business in question;

- The refusal to license prevents the appearance of a new product for which there is potential customer demand;

- The refusal is likely to exclude all competition in a secondary/ ancillary market.

In the IMS health case, IMS filed copyright violations against National Data Corporation Health Information Services (NDC) for its reports on sales of pharmaceutical products in the name of "brick" or "module." The infringement case was won by the IMS in Germany. Later on, NDC filed a complaint with the European Commission against IMS for abuse of dominant position. Commission held that it is not necessary that IMS open its market for competitors.

\section{Indian competition law}

Immediately after independence, the policy makers required immediate industrialization and they followed state intervention as a policy to achieve equitable distribution of wealth as envisaged in the Directive Principles of State Policy. ${ }^{105}$ In order to promote this policy, government of India appointed a Committee on Distribution

\footnotetext{
${ }^{100}$ Case C-238/87, AB Volvo v Erik Veng (UK) Ltd, [1988] ECR-6211.

101 Joined cases C-241/91 P and C-242/91 P, Radio Telefis Eireann (RTE) and Independent Television Publications Ltd (ITP) $v$ Commission of the European Communities, [1995] ECR I-00743 It was an appeal to Case T-69/89, Radio Telefis Eireann v Commission of the European Communities, [1991] ECR II-00485.

${ }^{102}$ Case T-504/93, Tiercé Ladbroke SA v Commission of the European Communities, [1997] ECR II-923.

${ }^{103} \mathrm{lbid}, \mathrm{n} .82$

${ }^{104}$ Case C-7/97 Oscar Bronner $\mathrm{GmbH}$ \& Co. KG v Mediaprint Zeitungs- und Zeitschriftenverlag GmbH \& Co. KG and Others [1998] ECR I-7791

${ }^{105}$ Article 39 (c) of the Indian Constitution provides that the operation of the economic system does not result in the concentration of wealth and means of production to the common detriment."
} 
of Income and Levels of Living, known as Mahalanobis Committee in 1960. In 1964, Government appointed Monopolies Inquiry Commission to examine and investigate the extent and effect of concentration of power in the private sector and its consequences on society; and to suggest necessary legislative and other measures in accordance with the findings. The committee found that there is high level of economic concentration in the Indian industry [14]. However, no legislation has been passed and in 1966 another committee named Hazari Committee to review the operations of the existing industrial licensing system under the Industries (Development and Regulation) Act, 1951. This Committee also concluded that the working of licensing system resulted in disproportionate concentration of wealth in some of the business houses in India. The Government in 1967, again appointed a committee known as Industrial Licensing Policy Inquiry Committee which was asked to look into the license raj and financing in the country. The Committee concluded that the licensing system was unable to check the concentration of wealth in the country and suggested for a comprehensive legislation known as Monopolies and Restrictive Trade Practices (MRTP) which provides for constitution of MRTP Commission to check the problem. This legislation ruled for 33 years in the country as a command-and-control system as far as restriction of monopolies is concerned.

Due to the liberalization of Indian economy in 1991 many provisions of the Act became obsolete. The present competition provisions can be traced back to the Monopolies and Restrictive Trade Practices Act, 1969 (MRTP Act) in India. There was no provision to control mergers and acquisitions. The elimination of quantitative restrictions in 2001 made the Indian industry open to competition from abroad. This led to the appointment of a high level committee by the Government of India under the chairmanship of Mr. S.V.S Raghavan to examine the relevance of MRTP Act and to suggest a full-fledged competition law in India similar to that in foreign countries. The committee recommended the scrapping of the MRTP Act and the adoption of a new law called the Indian Competition Act, 2002. After passing the Act, there was a unique situation where two Acts were in force for a period of two years to deal with the pending cases. The new Act was not activated and was not in force due to a Writ Petition filed in the Supreme Court of India questioning the constitutional validity of the Act. ${ }^{106}$ The interference of the Supreme Court delayed the implementation of the Act. An amendment was passed in 2007 to make the CCI an expert body and constitution of an appellate body. The amendment made vast changes to the 2002 Act in order to cope up with the changed business conditions in India.

The Patent Act also amended in 2005 to include product patent system in India which paved the way for greater protection for patents in the country in accordance with the TRIPs mandate. In one way intellectual property also creates competition in innovation. It provides protection for a limited period of 20 years exclusively. Even during this period the inventions can be used for research purposes and other exceptional purposes mentioned in the Patent Act. A compulsory license can be issued without the consent of the patent owner on grounds such as non-satisfaction of the requirement of the public; non working of the patent in India and refusal to license for a reasonable royalty.

The objective of the Act clearly spells out that "....to prevent practices having adverse effect on competition, to promote and sustain competition in markets, to protect the interests of consumers and to

${ }^{106} \mathrm{Brahm}$ Dutt v. Union of India, Writ Petition (civil) 490 of 2003 Judgment comes out in 2005. ensure freedom of trade carried on by other participants in markets, in India..."

The Act is divided into different kind of competition which is analyzed below in detail.

\section{Anti-competitive agreements}

Some agreement among enterprises has the potential of restricting competition. These agreements include a group of firms act together as a single firm; it can damage the market by thwarting competition. Anti-competitive agreements are divided into vertical and horizontal agreements. Vertical agreements are agreement between firms at different stage of production, e.g. an agreement to supply raw materials. Horizontal agreements are ones between firms at the same level of distribution. The provisions of competition law apply only when the agreements result in unreasonable restrictions on competition.

In a market, powerful enterprises can influence the market conditions in their favour by denying normal opportunity to others. A powerful position in market can be achieved by many ways. The firms may collude and exert their joint powers through agreements instead of competing against each other and a single firm achieving a dominant position in the market by itself [15].

Section 2(b) provides for an inclusive definition: the "agreement" includes any arrangement or understanding or action in concert, - (i) whether or not, such arrangement, understanding or action is formal or in writing; or (ii) whether or not "such arrangement," understanding or action is intended to be enforceable by legal proceedings. The definition includes both vertical as well as horizontal agreements.

Section 3 of the Act states that no enterprise or association of enterprises or person or association of persons shall enter into any agreement in respect of production, supply, distribution, storage, acquisition or control of goods or provision of services, which causes or is likely to cause an appreciable adverse effect on competition within India. However, Section 3 does not prohibit agreements between enterprises and persons. Section 3(1) clearly provides that no enterprise or a person shall enter into an agreement, which causes or is likely to cause an appreciable adverse effect on competition within India. But, if there is an allegation that an agreement is likely to cause appreciable adverse effect, then action will lie. The term "appreciable adverse effect on competition" has not been defined in the act. However, section 19(3) states that the commission shall have due regard to the following factors during the consideration under section 3(1):

- Creation of barriers to new entrants in the market;

- Driving existing competitors out of the market;

- Foreclosure of competition by hindering entry into the market;

- Accrual of benefits to consumers;

- Improvements in production or distribution of goods or provision of services;

- Promotion of technical, scientific and economic development by means of production court distribution of goods or provision of services.

Section 3(4) of the Act prohibits tie-in arrangement, ${ }^{107}$ exclusive

${ }^{107} \mathrm{Tie}$-in arrangement is defined as any agreement requiring a purchaser of goods as a condition of such purchase of some other goods. 
supply agreement, ${ }^{108}$ exclusive distribution agreement, ${ }^{109}$ refusal to deal ${ }^{110}$ and resale price maintenance. Any of these practices having adverse effect on competition in India is prohibited. It means that anticompetitive practice may happen inside or outside India, but if the effect is within the country, Indian competition authorities can take appropriate action. ${ }^{111}$ However, section 3(5) give the IP right holder to put restraint on infringement and to impose reasonable restrictions and conditions to protect his right on copyright, patents, trademarks, geographical indications, designs and semi-conductor layout designs.

Tie-in arrangement is described in Explanation to Section 3(4), that includes any agreement requiring a purchaser of goods, as a condition of such purchase, to purchase some other goods. Such agreement causes or is likely to cause an appreciable adverse effect on India will be considered as anti-competitive agreements.

\section{Abuse of dominant position}

The mere fact that a firm or enterprise or undertaking is in a dominant position in the relevant market alone is not prohibited by competition law. Section 4 of the Indian Act expressly prohibits abuse of dominant position. If an enterprise directly or indirectly, imposes unfair or discriminatory condition in purchase or sale of goods or service it will be considered as abuse of dominant position in the market. Section provides that "dominant position" means a position of strength, enjoyed by an enterprise, in the relevant market, in India, which enables it to- (i) operate independently of competitive forces prevailing in the relevant market; or (ii) affect its competitors or consumers or the relevant market in its favour. ${ }^{112}$

The definition of relevant market is important for the determination of abuse of dominant position with specific to that market. Section 2 ( $r$ ) of the Indian Act defines relevant market "means the market which may be determined by the Commission with reference to the relevant product market or the relevant geographical market or with reference to both the markets." The relevant geographical market also has been defined clearly as in Section 2(s) "a market comprising the area in which the conditions of competition for supply of goods or provision of services or demand of goods or services are distinctly homogenous and can be distinguished from the conditions prevailing in the neighbouring areas." The abuse of dominance is considered differently and it is broader than economic power over price. It is not same as economic monopoly, although a monopoly would clearly be dominant. ${ }^{113}$

The "rule of reason" approach developed by the US Supreme Court can be of great help to the framing and integration of the Indian Competition Act also. ${ }^{14}$ Section 4 of Indian Competition Act prohibits agreements, which causes or is likely to cause an "appreciable adverse effect on competition" within India. What amount of restriction qualifies to be called "appreciable" and what exactly is "adverse effect on competition" will have to be interpreted on case to case basis taking into account the peculiar features of Indian business and nature of its

\footnotetext{
108 "exclusive supply agreement" includes any agreement restricting in any manne the purchaser in the course of his trade from acquiring or otherwise dealing in any goods other than those of the seller or any other person;

109"Exclusive Distribution Agreement" includes any agreement to limit, restrict or withhold the output or supply of any goods or allocate any area or market for the disposal or sale of the goods:

110 "refusal to deal" includes any agreement which restricts, or is likely to restrict, by any method the persons or classes of persons to whom goods are sold or from whom goods are bought;

${ }^{111}$ Explanation to Section 3(4)

${ }^{112}$ Competition Commission of India, Advocacy Document

${ }^{113}$ OECD (2005): "Competition law and Policy in the European Union"

${ }^{114}$ Standard Oil Co. v. United States, 221 U.S. 1 (1911)
}

restriction and general economic condition of the nation as a whole. Under section 4 no enterprise shall abuse its dominant position. Dominant position is not clearly defined under the Act.

In a recent case, In Re M/s. SRS Real Estate Limited, the Competition Commission of India held that if there is more than one equal player in the same geographical area, there is no infringement of Section 8 and 4 of the Act. ${ }^{115}$ In In Re: IELTS Australia Pty Ltd., IDP Education Pty Ltd., IDP Education India Pvt. Ltd. and Planet EDU Pvt. Ltd., the petitioner alleged that the Party No. 3 is abusing its dominant position by representing to students as being the 'World's largest student placement and English Language Testing Service provider'. As per the IP, this assertion is not correct and is being made to restrict the competition in the business of educational counselling being carried by members of the Informant Association. The IP has alleged that the said parties are providing the same services as that of the members of the IP association free of cost to encourage the people to approach the test centre and take their advice. The Commission in this case held that different parties are active in different markets under Section 3(3) of the Act. The alleged violation of competition law in the information is of "tie-in arrangement". In this case the Commission found that both the services are, invariably, needed by consumers. No case of low quality product being offered is either claimed or made out. Moreover, there is no harm to the consumer; rather he is being substantially benefited (by an amount up to Rs. 10,000/- which is no longer required to be paid) if he avails both the services from the IDP India. Commission observed that two operations under the same roof could be a business decision to reduce the establishment cost and other operating expenses. This type of arrangement may bring efficiency and ultimately be beneficial to the consumers and does not violate any of the provisions of Competition Act. ${ }^{116}$

Delhi High Court in the case of Hawkins Cookers Limited v. Murugan Enterprises, held that a well known mark cannot be permitted to create the monopoly in the market on the basis of being well known mark by controlling the ancillary and incidental market. This is considered as abuse of dominant position and is prohibited. ${ }^{117}$ In this case the plaintiff alleged that the defendants used plaintiff's trademark HAWKINS in Defendant's product, pressure cooker gasket. The claim of the plaintiff was disputed by the defendant on the ground that the gaskets were being sold under their own trademark and the use of the word 'Hawkins' by the defendant on their products/gaskets was to inform the purchasers that the gaskets being manufactured by the defendant were suitable for Hawkins pressure cookers.

The defendant argued that the plaintiff wanted to monopolize the sale of gaskets which are used in pressure cookers in the market. The defendant manufactured gaskets which can be used for different types of pressure cookers including the pressure cookers manufactured by the plaintiff. The defendant claimed that it was a common knowledge that there was always a second line of manufacturers of spare parts, accessories and replacement items of machines, articles of everyday use, domestic appliances and even for automobiles for every description, which is known as ancillary industry. The case was decided against the plaintiff in this case.

Section 27 of the Act, the Competition Commission of India has the authority to penalize IPR holders who abuse their dominant position.

\footnotetext{
${ }^{15}$ Case No.65/2010 decided on 01.01.2011. MANU/CO/0001/2011 ${ }^{116}$ Case No.60/2010 decided on 22.12.2010. MANU/CO/0051/2010

${ }_{117} 2008$ (36) PTC 290(Del); MIPR 2008 (1) 128 The basis of decision in case was that plaintiff is trying to create monopoly in the market.
} 
Further, under Section 4 of the Act the Commission is also authorized to penalize the parties to an anti-competitive agreement, which is in contravention of Section 3 of the Act.

Dominance of an enterprise has to be judged by its power to operate independently under competitive circumstances. The Commission must take into account a number of indicators in the determination of dominant position such as market share, size and resource of the enterprise, importance of competitors in the market, economic power of the enterprise, vertical integration of the enterprises, entry barriers etc. which require a thorough economic analysis. In addition to pricefixing, certain practices such as collective will courts, market sharing etc. is considered as illegal under the Competition Act.

According to Section 18 of the Act "Subject to the provisions of this Act, it shall be the duty of the Commission to eliminate practices having adverse effect on competition, promote and sustain competition, protect the interest of consumers and ensure freedom of trade carried on by other participants, in markets in India." Accordingly, under the Act, the Commission is to take action against anti-competitive agreements (such as cartels) and abuse of dominant position (such as predatory pricing ${ }^{118}$ and unfair or discriminatory conditions of prices). The dominance of the enterprise has to be determined in accordance with the power to operate independently of competitive forces or to affect competitors or consumers in general. Market share alone is not the criteria for dominant position. The factors to be considered for the determination of dominant position are market share, size and resources of the enterprise, size and importance of competitors, economic power of the enterprises, vertical integration of the enterprises, entry barriers, etc. ${ }^{119}$ For the purpose of the Act the Commission will determine whether the "relevant market" is a "relevant geographical market" or a "relevant product market." The Commission will also consider the following factors for the consideration of relevant geographical market:

- Regulatory trade barriers

- Local specification requirements

- National procurement policies

- $\quad$ Adequate distribution facilities

- Transport costs

- $\quad$ Language

- Consumer preferences

- $\quad$ Need for secure or regular services or rapid after sales services.

In the determination of relevant product market the following factors to be considered by the Commission:

- Physical characteristics or end-use of goods

- $\quad$ Price of goods or service

- Consumer preferences

- Exclusion of in-house production

- $\quad$ Existence of specialised producers

- Classification of industrial products

118 "predatory price" means the sale of goods or provision of services, at a. price which is below the cost, as may be determined by regulations, of production of the goods or provision of services, with a view to reduce competition or eliminate the competitors. Explanation ii of Section $4(2)$

${ }^{119}$ Section $19(4)$
If the Commission found that any enterprise violated its dominant position in the market, not more than 10 per cent of its turnover can be imposed as penalties. It can pass a "cease and desist" order or such other order deems appropriate.

\section{Combinations}

Combination of enterprises may be done with different objectives, for example, to create shareholder value over and above that of the sum of merging companies. It can be of various forms like a merger, amalgamation, acquisition of shares, voting rights or acquisition of control over an enterprise or company.

The Competition (Amendment) Act, 2007 made significant changes to the competition regime in India ${ }^{120}$.Introduction of a mandatory notification process for persons undertaking combinations above the threshold is introduced by the amendment. Under the 2002 Act it was optional. The entities that want to enter into combinations shall notify the Commission in the specified form disclosing the details of the combination within 30 days of approval of the decision by the board of directors. 210 days period applies in case of cross border transactions. ${ }^{121}$ It is mandatory for a foreign company with assets of more than $\$ 500$ million that has a subsidiary in India with a substantial investment to notify the Commission before acquiring a company outside India. In 2008, Competition Commission of India promulgated a draft Competition Commission (Combination) Regulations. It was revised and published again in 2009 after industry feedback.

Combinations are defined in Section 5 of the Competition Act, 2002. Combination includes acquisition of control by a person over an enterprise where such person has control over another enterprise engaged in similar business. If a combination causes or is likely to cause an appreciable adverse effect on competition within the relevant market in India, it can be scrutinized by the Competition Commission. The Commission can issue notice to show cause accompanied by appropriate fees. The Commission can compel any parties to disclose or publish details of a proposed combination.

The Competition Act explicitly allows the commission to examine a combination effect outside India and pass orders against it provided that such combination has an adverse effect on competition in India. Similar provisions can be found in the anti-trust laws of the US and the EU Merger Regulation. The following transactions are exempted from the purview of the combination regulations framed under the Competition Act of India in 2007: -

- Any acquisition of shares or voting rights of a company of not more than 26 percent of the total shares or voting rights of the company.

- Any acquisition of assets that are not directly related to the business of the acquirer; however, this exemption would not apply where assets of the company that are being acquired represent the entire business operation in a particular location or relate to a particular product or service of such company.

The Regulations also provide that the acquisitions, as listed under a. and $b$. above, should be acquisitions which are made solely as an investment or in the ordinary course of business and which do not lead to control of the company by such acquirer.

- An acquisition of or acquiring of control of or an M\&A

${ }^{20}$ Priti Suri, 'Merger Review under the Competition Act: Regressive or Progressive Steps'.

${ }^{121}$ It is a long period of time when compare to the US provisions which provides for one month. 
transaction, where the domestic nexus for foreign parties engaged in a combination (i.e., with thresholds of Rs. 500 crores (approx USD 125 Million) of assets or Rs. 1500 crores (approx USD 375 Million) of turnover), does not comprise of assets of Rs. 200 crores (approx USD 50 Million) or a turnover of Rs. 600 crores (approx USD 150 Million), of each of at least two of the parties to such combination.

- Any acquisition of shares or voting rights of a company where the acquirer already holds more than 50 percent of the shares or voting rights of such company prior to the acquisition; and e. any acquisition pursuant to a bonus or rights' issue or subdivision of shares, but not including any acquisition resulting out of relinquishment of rights. Combinations which are an adverse effect on the relevant market in India is considered to be void.

\section{Mergers}

Mergers are a normal activity to expand the business, but this activity sometimes affects the competition in the market. Mergers can be horizontal or vertical. Horizontal mergers are between enterprises that are existing or potential competitors at the same level in the supply chain. Vertical mergers are between enterprises at different levels at the supply chain. If a merger is likely to give a controlling market power, such market concentration has to be controlled. Horizontal mergers are considered as more harmful with anticompetitive as well as monopoly effects. Vertical mergers are considered as less harmful as it benefits for the merging enterprises and for consumers. But if such a merger acquires sources of raw materials and deny the same to competitors, such merger could also facilitate collusion. Mergers are considered to be an economic activity which creates employment and most of the times good amount of foreign investment. If there is no collusive activity there is no harm on the economy rather there is economic benefits. But these collusive activities sometimes lead to anti-competitive activities in the market which is prohibited under competition laws. Mostly the companies use merger as a combination method to avoid competition in the market and consequently gain the market power. In each case the Commission would investigate the nature of action, relevant market and adverse effect on competition. ${ }^{122}$ The exceeding thresholds were explained in Section 5 of the Competition Act, 2007.

If the type of activity is in the nature of acquisition, amalgamation, merger or acquiring control of assets in India is more than Rs. 1000 Crores and in case of Indian and overseas assets, it is USD 500 million or more and turnover is Rs. 3000 Crores or more in India and involving Indian and overseas transactions are USD 1500 million or more. If the same kind of transactions involving a group of parties then the threshold in terms of assets are Rs. 4000 Crores or more and USD 2 billion and in terms of turnover Rs. 12000 Crores or more and USD 6 billion respectively. A joint venture can be established by acquisition of shares in an existing company also would fall within the definition of a combination under Section 5 of the Act and have to be notified if the thresholds are met under the Section. This is applicable even though the transaction is happened before the amendment. ${ }^{123}$ In a recent case the CCI held that "an enterprise holding a market share below 17 per cent cannot be said to be capable of 'operating independently of competitive forces' and/or 'affecting its competitors or consumers or the relevant market in its favour ${ }^{124}$.

${ }^{122}$ Poulomy Chatterjee, Horizontal Merger Guidelines, CCI, New Delhi

${ }^{123}$ This follows from the judgment and order of 31.03.2010 in the Kingfisher Airlines case in The High Court of Bombay, WP. No. 1785/2009

${ }^{124}$ Case No. 5/2009, decision dated 02.12.2010
A number of factors to be taken into consideration by the Commission for the determination of applicable adverse effect on completion they are:

- Actual and potential level of competition through imports in the market

- Extent of barriers to entry into the market

- Level of competition in the market

- Likelihood that the combination would result in the parties to the combination being able to significantly and sustainably increase prices or profit margins

- Extent of effective competition likely to sustain in a market

- Extent to which substitutes are available or are likely to be available in the market

- Market share, in the relevant market, of the persons or Enterprise in a combination, individually and as a combination

- Likelihood that the combination would result in the removal of a vigorous and effective competitor or competitors in the market

- Nature and extent of vertical integration in the market

- Possibility of a failing business

- Nature and extent of innovation

- Relative advantage, by way of the contribution to the economic development by any combination having or likely to have appreciable adverse effect on competition

- Whether the benefits of the combination outweigh the adverse impact of the combination, if any

\section{Predatory pricing}

Predatory pricing was considered by the Monopolies and Restrictive Trade Practices Act, 1969 (MRTP Act) as a Restrictive Trade Practice. According to the relevant provision in the said Act, an agreement to sell goods at such prices as would have effect of eliminating competition or competitor is a Restrictive Trade Practice, prejudicial to public interest. In 1996 in Modern Food Industries case the MRTP Commission applied the provision to a single seller on the ground that "in fixing the prices, there is an understanding that the seller will sell the product at a particular price", bringing the practice within the purview of the relevant provision of the MRTP Act. The Commission observed that the essence of predatory pricing is pricing below cost with a view of eliminating a rival. The charge against Modern Food Industries was that it was selling bread at a price lower than the cost of production in order to eliminate its competitors from the market. It was also charged with the motive that it would increase the price of bread unreasonably, once it attained a dominant position in the market. In this case the prosecution could not establish the offence with accurate evidence, but the Commission defined what constitutes predatory pricing. The two principles enunciated in this case are (a) evidence of pricing below costs and (b) intent to eliminate competition. These are in conformity with the international practice in predatory pricing cases. ${ }^{125}$

Predatory pricing is allowed to meet the competition in market under Competition Act 2002. In the case of Sh. Neeraj Malhotrav.

${ }^{125}$ CUTS 30th Anniversary Lecture Series 
Deustche Post Bank Home Finance Limited (Deustche Bank) and Ors, ${ }^{126}$ Director General of the Competition Commission investigated the case and found that levying of prepayment penalty creates a barrier to new entrant in the market in way that if the new entrant is providing competitive/lower interest rates, better services etc. the borrower of the existing banks can only avail the services of the new entrants by incurring additional cost in the form of pre-payment charges. Levying of pre-payment penalty by banks makes the exit expensive thus acts as a deterrent for a borrower in availing the best prevailing interest rate of other bank/financial institution and thus violated Section 3(3) (b) of the Competition Act. The common decision of the banks to charge prepayment penalty limits market competition as anticompetitive and anti-consumer. Thus the banks violated Section 19(3) (a) (c) and (d) of the Act.

However, CCI ruled that the price below the production cost is to meet the competition in relevant market. So it is not a predatory pricing. 'Rule of reason' test was used in this case. Predatory pricing can be calculated by economic perspective as well as non-economic. In economic approach marginal cost or average variable cost is used to analyse below the cost of production prices. In non economic approach, any price below the cost of production is predatory pricing ${ }^{127}$. In USA antitrust case law, various tests are evolved to check the predatory pricing ${ }^{128}$. These are "price cost comparisons' (Areeda Turner test ${ }^{129}$ and its variants), Williamson's output restriction rule or Baumol's permanence"130 etc. These tests can be helpful to CCI also to test the predatory pricing.

\section{IPR and competition}

Intellectual Property Rights involve grant of exclusive license to the right holders to exploit the result of their inventions for a limited period of time. Section 3(5) of the Indian Competition Act exempts reasonable use of such inventions from the purview of competition law. But Section 4(2) says that actions by enterprises that shall treated as abuse be equally applicable to IPR holders as well. Section 3 prohibits anticompetitive practices, but this prohibition does not restrict "the right of any person to restrain any infringement of, or to impose reasonable conditions, as may be necessary for protecting any of his rights" which have been conferred under IPR laws like Copyright Act, 1957, Patents Act, 1970, the Geographical Indications of Goods (Registration and Protection) Act, 1999 (48 of 1999), The Designs Act, 2000 and the Semi-conductor Integrated Circuits Layout-Design Act, 2000. It means that an IPR holder cannot put any unreasonable conditions while licensing his intellectual property which will be considered as violating the competition law. It includes any restrictions between the licensor and the licensee to restrict production, distribution, exclusivity conditions, restricting quantities and prices, patent pooling and tiein arrangements. In such cases the competition commission can pass a variety of orders like cease and desist, changes to the licensing agreements as it deems fit.

Section 3(5) is incorporated in the Competition (Amendment) Act, 2007 to deal with intellectual property and anticompetitive practices. This provision generally excludes IPR protection, but this is subject to "reasonable" condition and the unreasonable conditions or abuse

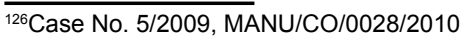

${ }^{127}$ Department of Justice (2002) What Is Competition? by William J. Kolasky, U.S. Department of Justice

${ }^{128}$ Brooke Group v. Brown \& Williamson Tobacco, 509 U.S. 209 (1993)

${ }^{129}$ Under this test predatory only when these are below marginal cost. If marginal

cost is not available than Average variable cost can be used

${ }^{130}$ David Spector, "Definitions and criteria of predatory pricing, working paper
}

of dominant position will attract Section 3. Abuses are explained in section 4 as follows:

- Imposition of unfair or discriminatory conditions on price

- Limiting or restricting the production of goods or services or market

- Limiting or restricting technical or scientific development to the prejudice of consumers

- Concluding of contracts subject to acceptance by other parties of supplementary obligations which have no use or no connection with such contracts.

- Denying market access in any manner

- Using dominant position to protect or enter into another market

The merger or forming consortiums for $\mathrm{R} \& \mathrm{D}$ may also affect effective competition. The exclusive licensing and cross licensing may give rise to competition issues in the case of grant back clause and market dominance. Patent pooling can be another restrictive practice which may be used to facilitate price collaboration.

The conflict between Competition law and IPRs came before Monopolistic and Restrictive Trade Practices Commission (MRTP Commission, predecessor to the Competition Commission) in the case of Vallal Peruman and Others versus Godfrey Phillips India Limited ${ }^{131}$. The commission observed:

"Trademark owner has the right to use the trademark reasonably. This right is subject to terms and conditions imposed at the time of grant of trademark. But it does not allow using the mark in any unreasonable way. In case, trademark owner abuses the trademark by manipulation, distortion, contrivances etc., it will attract the action of unfair trade practices." While presenting the goods and merchandise for sale in the market or for promotion thereof, the holder of the trademark certificate misuses the same by manipulation, distortion, contrivances and embellishments etc. so as to mislead or confuse the consumers, he would be exposing himself to an action of indulging in unfair trade practices. ${ }^{132}$ Licensing arrangements likely to affect adversely the prices, quantities, quality or varieties of goods and services will fall within the contours of competition law as long as they are not in reasonable juxtaposition with the bundle of rights that go with IPRs. Unreasonable conditions under Section 3(5) of the Indian law is thus prohibits the unreasonable use or exploitation of intellectual property rights.

Competition policy of India, ${ }^{133}$ states that "all forms of intellectual property have the potential to violate the competition". Intellectual property is not differentiated from other tangible properties for the purpose of competition law. So CCI can adjudicate matters relating to IPRs. The competition commission can decide constitutional, legal and even jurisdictional issues except the validity of statute under which tribunal is established ${ }^{134}$. In the case of Amir Khan Productions Private Limited $v$. Union of India, the court ruled that competition commission has the power to deal with intellectual property cases. What can be contested before copyright board can also be contested before

\footnotetext{
131(1995) 16 CLA 201; the same principle was re-iterated in Manju Bhardwaj v. Zee Telefilms Ltd. (1996) 20 CLA 229

${ }^{132}$ CUTS, Why India Adopted Competition Laws, 2006

${ }^{133}$ Based on Raghvan Committee Report, the high level committee report on Competition Law 2002

${ }^{134}(112)$ Bom LR3778
} 
Competition Commission Competition Act, 2002 has overriding effect over other legislations for the time being in force ${ }^{135}$.

In Amir Khan Private Limited versus Union of India, ${ }^{136}$ FICCI filed information against united producers/distributors forum (hereinafter called as UPDF) and others for market cartel in films against the Multiplexes. In order to raise their revenue, UPDF refused to deal with multiplex owners. Multiplex business is 100 percent dependent upon films. So this is refusal to deal and anti-competitive. The UPDF and others hold almost 100 percent share in Bollywood film industry. UPDF was indulged in limiting/controlling supply of films in the market by refusal to deal with Multiplexes. It is violation of Section 3(3) of Competition Act 2002. CCI prima facie found there is anticompetitive agreement and there is abuse of dominant position also. So CCI directed Director General (hereinafter called as DG) to inquire into the matter. DG inquired into the matter and submitted a report that there is cartel. CCI issued a show cause notice. UPDF instead of answering to show-cause notice, the complainant approached the Bombay High Court. UPDF contended that films are subject to copyright protection ${ }^{137}$. Therefore Copyright board has the jurisdiction to deal with matter. Furthermore, contended that for exclusive license, only remedy is compulsory license available under Copyright Act. So petitioner challenges the action taken by the CCI on the ground of lack of jurisdiction. Though, the issue was discussed earlier in Kingfisher v. Competition Commission of India. ${ }^{138}$ However, considering the importance the matter, Bombay High Court discussed the matter in great detail. The court ruled that Section 3(5) provides that Section 3(1) shall not take away the right to sue for infringement of patent, copyright, trademark etc. All the defences which can be raised before copyright board can also be raised before CCI. Competition law does not bar application of other laws ${ }^{139}$. Matter is sub- judice before CCI.

Patent pools are another area of conflicting stage with competition law. A patent pool is an agreement between two or more patent owners to license one or more of their patents to one another, or to license them as a package to third parties. ${ }^{140}$ Under the patent pool the entire group of patent is licensed in a package to produce a product. ${ }^{141}$ The co-operative arrangement becomes a bundle of rights hold by a group of people, those patents which are necessary for the development of the process or product. Patent pools have history of innovation and developing new products.

In 1856, the Sewing Machine Combination formed one of the first patent pools consisting of sewing machine patents. ${ }^{142}$ Another example of a patent pool is the Manufacturers Aircraft Association formed in 1917 to license a number of patents necessary for the manufacture of airplanes. ${ }^{143}$ But patent pools may have anti-competitive effects as well. One of the recent patent pools formed in 1997 was the formation of MPEG-2 compression technology ${ }^{144}$ If the poolers are downstream users of the patent and they refuse to license the technology to third

\footnotetext{
${ }^{135}$ Section 60 of the Competition Act 2002

${ }^{136} 2010$ (112) Bom LR3778

${ }^{137}$ Section 13(1) (b) and 14(1)(d)(ii)

${ }^{138}$ Writ petition number 1785 of 2009 , Vodafone International Holdings BV v Union

of India, 2009 (4) Bombay Cases Reporter 258 (DB)

${ }^{139}$ Section 62 of the Competition Act 2002

${ }^{140}$ Merges R. Institutions for intellectual property transactions: The case for patent pools

${ }^{141}$ United States v. Line Materials, 333 U.S. 287, 313

${ }^{142}$ Privacy Versus Government Surveillance: Where Network Effects Meet Public Choice

${ }^{143}$ Carl Shapiro, Navigating the Patent Thicket: Cross Licenses, Patent Pools and Standard Setting, in Jaffe, Lerner and Stern (eds.) Innovation Policy and the

Economy, The MIT Press: Cambridge, London, p.127.

${ }^{144}$ Department of Justice (Business Review)
}

parties causes downward societal welfare which is per se anticompetitive in nature. An agreement between two firms to restrict competition in the market in any form is prohibited by competition laws of countries. One of the most famous US case on the subject is the bursting of patent pool on glass manufacturing through the case Hartford-Empire Co. $v$. United States. ${ }^{145}$

The patent pooling can have pro-societal effects when it integrates complex technologies for the production of new products. It reduces transaction cost and patent infringement litigation between companies and promotes innovation and transfer of technology. Such patent pooling is anticompetitive if the excluded firms cannot actively compete in the market and the patent poolers actively dominate the relevant market and the object of such pooling is not for the efficient development and dissemination of the technology. ${ }^{146}$ So patent pools have social and economic benefits and abuse of such patent monopoly is anticompetitive in nature and the competition law has to counter such abuses [16].

\section{Conclusions}

The growing importance of innovation is indisputable. The goals of IP promote innovation, creativity and diffusion of technology. The basic role and function of completion law is to prevent anticompetitive practices that harm economic efficiency and increase transaction cost. Dynamic efficiency, economic efficiency and welfare of consumers should be the prime importance in both cases. Competition in the market has to consider the IPR rights of innovators which always boost the market. After analysing the legislations and cases reveals that competition law is not sufficiently equipped with the analytical tools necessary to find out the IPR protection implications, both the set of laws (Competition and IPR protection) share the same basic objectives, promotion of innovations and welfare of society. A comprehensive competition policy for IPR is required in the field of licensing agreements, control of market dominance and mergers in all jurisdictions. Long term efficiency should be promoted rather justified from a short-term point of view. The IP and competition law objectives are consistent and compatible. The competition law intervention is required only when there is an abuse of monopoly rights. Many of the IP licensing practices like tying, grant backs and pooling are not intrinsically restrictive in nature.

There is far reaching evolution of the approaches to IP licensing and patent pooling by understanding the role of IP rights and the importance of IP licensing. The restrictive practices in the era of "Nine no Nos" has given way for the "rule of reason" approach. The new enforcement approaches to patent thickets are taken to the need of new economies. The jurisdictions under discussion, the US and EU markets, competition law enforcement have strengthened. India is in a normative stage and competition law has to get more teeth to deal with IP abuses.

Competition policy is an effective counterbalance to protecting intellectual property rights. The TRIPs Agreement provides a basic framework of intellectual property protection as well as enforcement of anti-competitive licensing practices in intellectual property. Article $8(2)$ of the Agreement gives a general direction that appropriate measures may be needed to prevent the abuse of intellectual property rights by its holders. Article 40(1) recognizes that the licensing practices that restrain competition may have adverse effect on trade or impede

\footnotetext{
$\overline{145323 \text { U.S. } 386(1945)}$

${ }^{46}$ UD Department of Justice Guidelines for the Licensing of Intellectual Property, 1995
} 
technology transfer. Article 40(2) permits the members to specify anticompetitive practices constituting abuse of IPRs and to adopt measures to prevent or control such practices. Such practices can included exclusive grant backs, clauses in the agreement preventing validity challenges and coercive package licensing. Article $31(\mathrm{k})$ clearly provides that a practice determined after judicial or administrative process to be anti-competitive, a compulsory license can be granted. But the TRIPs unanswered certain questions like the standard of practices under which actionable abuses determined. India enacted its competition law in 2002 and amended in 2007 in order to give full effect to the Act and in order to cope with the changing needs of the Indian business scenario and economy. If the Competition Commission of India found dominant position made out under Section 27(g), Commission can hold an enquiry and pass appropriate orders. But licensing and other IP issues has yet to come before the Commission and the Appellate Tribunal Specially Constituted for competition cases under the 2007 amendment to the Act. When comparing the provisions of US, EU and Indian provisions of competition law, Indian law has followed European model. Article 85 of the Rome Treaty ${ }^{147}$ and Section 1 of the Sherman Act prohibits agreements in restraint trade. Under the US law price fixing related cartel is treated penal in nature and huge damages were paid. EU law is with many exceptions and the enforcement is very liberal. EU law considers that 40 per cent market share is sufficient to constitute dominance. ${ }^{148}$

In India, there are sectoral regulators and the patent issues are exclusively dealt by the Patent Offices in India. In US and EU any competition matter is dealt by the competition authorities irrespective of the sector, but still there is no clarity in the Indian legislation. The sectoral competition issues have to be dealt by the competition commission. The objective of competition law throughout the world is consumer welfare. The extra territorial jurisdiction (US, EU and India) of competition commissions in three jurisdictions are recognized when such transactions affects the local market. Each jurisdiction has a mandatory merger notification procedure where large transactions are involved with domestic or foreign companies. The competition Act has not fully emerged to the level of developing jurisprudence on the subject with regard to the conflict between competition and intellectual property. The difficulties in implementing the provisions are yet to be encountered by the Commission.

\section{Suggestions}

The complexities of the provisions in different jurisdictions have diverse implications and approaches. In the US, there are several cases of abuse of dominance and non-disclosure of patents to standard setting organizations. There should be tougher approaches to monopolization of relevant market and abuse of dominance like the EU stance on Microsoft case. The IP licensing practices should have been clear cut guidelines as in the case of both US and EU. India should also develop such guidelines for better management of a largest market economy in the world. The exhaustion of IP rights to be reiterated in domestic laws so that parallel import of technologies can take place without violating patent laws, The interventionist approaches like IMS Health and Magill to be taken rather than the US approach like in the Trinko in refusal to deal cases. The enforcement policies must have a direct connection with economic policies and developmental goals of developing countries. It may differ from economy to economy and blanket imitation of US and EU policies and implementation in India is not going to work properly. Continued focus of IP protection in the

\footnotetext{
${ }^{147}$ The Treaty established the European Union.

${ }^{148}$ Hoffmann-La-Roche v. Commission (Case 85/76, 1976, ECR 461, Para 38)
}

pharmaceuticals sector have implications for developing countries like India and other least developed countries in countering diseases like HIV/AIDS. Aggressive enforcement of IP rights and countering with competition law will increase the transaction cost and diminish the social welfare. It is important to recognize that more than 100 countries have enacted competition laws and at the same time more than 159 countries have IP laws in place, and both enforcing authorities must have a role in IP and competition law policy making, especially in developing countries. The guidelines developed by the US and EU in dealing with IP and competition issues can be used as a base on the background of TRIPs Agreement in order to deal with anti-competitive practices in technology licensing and transfer. More guidance is required in terms of legislative framework on the backdrop of available jurisprudence in the US and the EU which can be helpful in IP and competition policy formulation in countries like India.

\section{Acknowledgement}

The author is thankful to Microsoft India (Pvt) Ltd. for providing necessary scholarship for conducting this study.

\section{References}

1. Gormsel LL (2006) Article $82 \mathrm{EC:} \mathrm{Where} \mathrm{are} \mathrm{we} \mathrm{coming} \mathrm{from} \mathrm{and} \mathrm{where} \mathrm{are} \mathrm{we}$ going to?" The Competition Law Review 2: 5.

2. Correa C (2007) Intellectual Property and Competition Law. ICTSD Intellectua Property and Sustainable Development Series: 21.

3. Raju KD (2013) The Inevitable Connection between Intellectual Property and Competition Law: Emerging Jurisprudence and Lessons for India, Journal of Intellectual Property Law, 18: 111-122.

4. Bork RH (1996) The Rule of Reason and the Per se Concept: Price Fixing and Market Division II. Yale Law Journal 75: 373

5. Kusske KA (1984) Refusal to Deal as a Per Se Violation of the Sherman Act: Russell Stover Attacks the Colgate Doctrine. The American University Law Review 33: 463-491.

6. Roland Mussard (1962) The Regulation of Restrictive Business Practices under the Common Market Treaty in Restrictive Practices, Patents, Trade Marks and Unfair Competition in the Common Market, International and Comparative Law Quarterly Supplementary Publication 4: 17.

7. Mc Lachlan DL, Swan D (1963) Competition Policy in the Common Market. The Economic Journal 73: 54-79.

8. Peeperkorn, Luc (2003) IP Licenses and Competition Rules: Striking the Right Balance. World Competition: Law \& Economics Review 26: 4

9. Maskus KE (1999) Competition Policy and Intellectual Property Rights in Developing Countries: Interests in Unilateral Initiatives and A WTO Agreement World Bank Global Conference on Developing Countries and the Milllenium Round, Geneva.

10. Brodley JF (1987) The Economic Goals of Antitrust: Efficiency, Consumer Welfare and Technological Process. New York University Law Review 62: 1041-1042.

11. Tsenchov G (2010) Latest Development in the Microsoft Case in the European Union: Microsoft Officially Allows Browser choice to Customers. The Columbia Journal of European Law 16: 85-88.

12. Oscar Bronner GmbH \& Co. KG v (1998) Mediaprint Zeitungs and others European Court reports I: 07791.

13. Hanlen EO (2006) Refusla to Supply: Jurisprudence in European Competition Law since Oscar Bronner. Trinity College Law Review 9: 156.

14. Roy A, Jayant K (2008) Competition Law in India, Kolkata: Eastern Law House: 19: 522

15. Neale AD, Goyder DG (1981) The Antitrust Laws of the United States of America: A Study of Competition Enforced by Law.

16. Rodriguez V (2010) Patent Pools: Intellectual Property Rights and Competition Open AIDS J 4: 62-66. 